\title{
O rzekomej fundacji biskupstwa w Miśni 2 stycznia 968 roku
}

I.

W studium ogłoszonym w poprzednim tomie Roczników Historycznych Wojciech Jasiński ${ }^{1}$ podjął się krytycznej oceny dotychczasowego stanu badań nad datowanym na 2 stycznia 968 r. dokumentem dla Miśni wystawionym przez Jana XIII (dalej cyt. jako DM), starając się zweryfikować od podstaw - poczynając od ponownej analizy całości przekazów rękopiśmiennych - wszystkie argumenty pojawiające się w dotychczasowej dyskusji nad dokumentem, ale zarazem wprowadził kilka własnych. Jednak głównym powodem zainteresowania tym dokumentem jest dostrzeżenie przez W. Jasińskiego znaczenia, jakie ustalenie jego autentyczności może mieć dla kwestii związanych z początkami Kościoła w Polsce. Autor - przyjmując, że dokument jest autentyczny - traktuje opisaną w nim sprawę jako analogię do sytuacji towarzyszącej powstaniu pierwszego biskupstwa polskiego. Zdaniem W. Jasińskiego, DM świadczy, że biskupstwo w Miśni zostało ufundowane w styczniu 968 r. na kilka miesięcy przed erygowaniem metropolii w Magdeburgu (październik 968 r.) i do czasu podporządkowania go tamtejszemu metropolicie w końcu 968 r. było biskupstwem egzymowanym. Autor sądzi, że to przypadek Jordana i fundacja biskupstwa w Polsce zainspirowały cesarza Ottona I do wykorzystania tego samego rozwiązania prawnego w przypadku biskupstwa w Miśni. Tak więc w wystawionym w tym samym czasie domniemanym dokumencie papieskim dla Jordana miałaby zostać użyta ta sama (lub bardzo podobna) formuła prawna, czyli egzempcja (s. 35). Gdyby wnioski wynikające z dociekań W. Jasińskiego udało się utrzymać, byłby to poważny postęp w naszej znajomości początków Kościoła w Polsce. W niniejszym tekście postaram się jednak wykazać, że tezy o autentyczności dokumentu miśnieńskiego nie da się obronić.

${ }^{1}$ W. J a s i ń s k i, Bulla Jana XIII dla biskupstwa w Miśni z 2 stycznia 968 roku - falsyfikat czy autentyk? Przyczynek do studiów nad początkami Kościołów miśnieńskiego i poznańskiego, Roczniki Historyczne 79, 2013, s. 7-38.

Użyte skróty: MGH - Monumenta Germaniae Historica, DD - Diplomata regum et imperatorum Germaniae, z syglą danego władcy (O I, O II lub O III dla Ottonów i H II, H III lub H IV - dla kolejnych Henryków; K II - Konrad II, L III - Lotar III); PU - Papsturkunden 896-1046, wyd. H. Zimmermann, t. I-III, Wien 1984-1989. 
W. Jasiński stoi na stanowisku, że tekst dokumentu Jana XIII, w znanej nam postaci (poza dwiema interpolacjami z grupy rękopisów F, C, D), jest w całości autentyczny. Podobieństwa do datowanego na ten sam dzień dyplomu papieskiego (bez wątpienia autentycznego) dla opactwa w Hersfeld (dalej cyt. jako DH), w którym zostało ono egzymowane spod władzy miejscowego biskupa, wynikają z faktu, iż oba dokumenty przygotował ten sam kancelista Stefan, oraz z analogicznych - przynajmniej w zakresie odnoszącym się do klasztorów - rozporządzeń obu dokumentów papieskich. Zbieżności między DH a DM są szczególnie uderzające dlatego, że DM przygotowano wyłącznie na podstawie już gotowego $\mathrm{DH}^{2}$. W. Jasiński przyjmuje zatem - za Joachimem Huthem ${ }^{3}$ - stanowisko, które można określić jako maksymalistyczne, gdyż inni badacze tego zabytku (m.in. Karl Uhlirz i Harald Zimmermann) uważali, że za podstawę DM służył jakiś autentyczny, zaginiony przywilej Jana XIII dla klasztoru w Miśni, lecz znany tekst jest w znacznym stopniu, zwłaszcza w odniesieniu do tej części, która jest interpretowana jako egzempcja biskupstwa, podfałszowany. Nie wyliczam już badaczy uznających ten dokument w całości za fałszerstwo, które przygotowano na podstawie wspomnianego przywileju dla klasztoru w Hersfeld ${ }^{4}$.

Część argumentów za autentycznością DM W. Jasiński przejął z trwającej już 130 lat dyskusji nad DM. Jednak Autor nie zauważył, że niektóre z nich - formułowane przecież kilkanaście dekad wcześniej - możemy obecnie łatwo zweryfikować, dysponując pełniejszą wiedzą. Dotyczy to m.in. przytoczonej przez Autora opinii K. Uhlirza z 1895 r. (s. 10), że jest mało prawdopodobne, aby fałszerz przeprowadził specjalną kwerendę poza Miśnią w celu znalezienia odpowiedniego dokumentu papieskiego, który mógłby wykorzystać do fałszerstwa. Opinia Uhlirza opiera się na doświadczeniu, które rzeczywiście potwierdza taką tendencję ówczesnych fałszerzy, gdyż jako podkładek używali dokumentów z najbliższego otoczenia, najczęściej z zasobów rodzimej instytucji, ale nie jest to jednak regułą, która by wykluczała wykorzystanie oryginalnego dokumentu znajdującego się w innej instytucji, np. w klasztorze w Hersfeld, przez fałszerza pracującego na rzecz biskupstwa w Miśni ${ }^{5}$.

2 Tej ścisłej zależności dowodzi fakt, że w DM partie wspólne z Liber diurnus (LD) nie przekraczają tych zapożyczeń z LD, które znajdują się w DH. Innymi słowy, DM nie zawiera żadnej nadwyżki pochodzącej z LD w stosunku do DH, czyli jest po prostu nieprawdopodobne, aby kancelista, korzystając nawet wyłącznie $\mathrm{z}$ tych samych formularzy w LD, napisał tekst pod tym względem identyczny.

3 J. Huth, Neues zur Missions- und Frühgeschichte des Bistums Meißen und seiner Nachbarn. Das heidnische und christliche Slaventum, w: Acta II Congressus internationalis historiae Slavicae Salisburgo-Ratisbonensis anno 1967 celebrati, Wiesbaden 1970, s. 76-78; t e n ż e, Die Frühgeschichte der Bistümer Meissen und Prag im Lichte der Bulle „Si semper sunt" vom 2. I. 968, Annales Instituti Slavici. Veröffentlichungen des Institutum SalisburgoRatisbonense Slavicum Salzburg-Wien-Regensburg 8 (Millenium Dioeceseos Pragensis 9731973. Beiträge zur Kirchengeschichte Mitteleuropas im 9.-11. Jahrhundert), Wien 1974.

${ }^{4}$ Omówienie u Th. L u dw i g, Die Urkunden der Bischöfe von Meißen. Diplomatische Untersuchungen zum 10.-13. Jahrhundert, Köln-Weimar-Wien 2008 (Beihefte zum Archiv für Diplomatik 10), s. $250 \mathrm{n}$.

5 Np. fałszywy dyplom dla klasztoru Waulsort (PU nr 241, rzekomo z 976 r.) został w XII w. sfałszowany na podstawie przywileju papieża Benedykta dla klasztoru Św. Pantaleona w Kolonii z 976 r. 
Autor powtarza kolejny argument K. Uhlirza, że skopiowanie monogramów cesarskich w kopii B dokumentu miśnieńskiego, wobec braku ich w kopiach DH, świadczy, że DM został lepiej zredagowany. Niestety K. Uhlirz się mylił, gdyż fałszerze niekiedy byli w stanie sprokurować nawet dobre kopie pieczęci, nie mówiąc o monogramach, które łatwo było naśladować, mając do dyspozycji jakiś autentyczny dokument danego władcy. Z drugiej strony, brak monogramu na kopiach autentycznego DH nie stanowi podstawy do podejrzeń o nieautentyczność. Jeśli uznamy DM za fałszerstwo, to wiemy, że fałszerz korzystał z oryginalnych dokumentów Ottona I i Ottona II, z których mógł monogramy skopiować. Jeśli ewentualnie fałszerz miał dostęp do dokumentu w Hersfeldzie, to mógł też widzieć (i skopiować) oryginalne (zachowane do dzisiaj) dokumenty obu Ottonów dla Hersfeldu z 968 r. (MGH DD O I, nr 356; O II, nr 17), w których zostały potwierdzone papieskie przywileje dla klasztoru. Na nic nie zda się cytowana (s. 11) opinia J. Hutha (rzekomo wypowiedziana przez Leo Santifallera), że żaden z dokumentów papieskich tego okresu, który opierał się na Liber diurnus (dalej cyt. jako LD) nie okazał się falsyfikatem (zatem DM również), gdyż przeczą temu fakty... i sam Santifaller. Znamy sporo takich fałszerstw ${ }^{6}$.

Jednym z nowszych argumentów (wprowadzony przez H. Zimmermanna), który może wydawać się rzeczywiście przekonujący, jest odwołanie się do wzmianki w przywileju Innocentego II z 1131 r. dla biskupstwa w Miśni, w którym przypomniany jest jakiś wcześniejszy przywilej dla Miśni bliżej niesprecyzowanego papieża Jana. Wprawdzie jest tam mowa o posiadłościach biskupstwa, o czym DM milczy, ale też mamy ogólnikowe potwierdzenie granic diecezji, które szczegółowo są opisane w DM7 ${ }^{7}$. W. Jasiński przywiązuje jednak zbyt wielką wagę do tej wzmianki, gdyż nie może ona przecież dowodzić autentyczności DM. Przecież zarówno Innocentemu II, jak i biskupom podpisanym potem na widymusie mógł ktoś przedstawić fałszerstwo naśladujące oryginalny dyplom papieski. Zatem wzmianka z 1131 r. przesuwa jedynie czas sporządzenia ewentualnego fałszerstwa (lub jego wcześniejszej wersji) z połowy XIII w. - jak dotąd najczęściej przyjmowano - na okres przed $1131 \mathrm{r}$. Nie są to jedynie teoretyczne dywagacje, ale mamy fakty, które takie założenie uprawdopodobniają. Wiemy, że za pontyfikatu miśnieńskiego biskupa Godebolda (1120-1140) sprokurowano fałszerstwo pod imieniem jednego z jego poprzedników, Bennona (1066-1106), i skutecznie przedstawiono je Innocentemu II do zatwierdzenia ${ }^{8}$. W 1137 r. ten sam papież rozstrzygnął na korzyść Miśni spór z Magdeburgiem

${ }^{6}$ Por. PU nr $\uparrow 6, \uparrow 24, \uparrow 29, \uparrow 43, \uparrow 50, \uparrow 70$ itd. Por. zestawienie L. S a n t i fa 11 e r, Die Verwendung des Liber Diurnus in den Privilegien der Päpste van den Anfängen bis zum Ende des 11. Jahrhunderts, Mitteilungen des Instituts für Österreichische Geschichtsforschung 49, 1935, s. 258 n; H. H. A n t o n, Der Liber Diurnus in angeblichen und verfälschten Papstprivilegien des früheren Mittelalters, w: Fälschungen im Mittelalter, t. III, Hannover 1988, s. 115-142.

7 Urkundenbuch des Hochstifts Meissen, t. I, wyd. E. G. Gersdorf, Leipzig 1864 (Codex diplomaticus Saxoniae Regiae II 1), nr 45, s. 48: Gedobolde episcope, Misennensi ecclesiae - - salubriter providentes tuis iustis postulationibus clementer annuimus, et tam ipsam quam omnia ad eam pertinentia ad exemplar praedecessoris nostri felicis memoriae Johannis papae apostolicae sedis privilegio communimus. I nieco dalej: Praeterea parrochiales terminos, quos Mesennensis ecclesia legitime usque ad haec tempora noscitur habuisse, per praesentis scripti paginam tibi tuisque successoribus confirmamus.

8 Tamże, $\mathrm{nr} 47$. 
o przynależność Dolnych Łużyc, m.in. na podstawie jedynie konceptu dokumentu, który swego czasu bezskutecznie próbowano uzyskać od Ottona III ${ }^{9}$. W końcu ci sami biskupi, którzy wystawili widymus DM w 1250 r., w tym samym dniu widymowali ewidentnie fałszywy, choć zręcznie udający oryginał, dyplom (zachowany do dzisiaj) wystawiony rzekomo przez Ottona I 19 X 968 r. $^{10}$

II.

Do wniosku, że dokument miśnieński jest autentykiem, doprowadziły W. Jasińskiego następujące przesłanki:

1) Analizowane różnice części formularzowej DM i DH pokazują (s. 20-25), że ,żaden z wariantów formularzowych bulli miśnieńskiej w stosunku do hersfeldzkiej nie ma proweniencji trzynastowiecznej, a wszystkie te odmianki albo znajdują potwierdzenie $w$ innych dokumentach Jana XIII, albo znane były przed czasem wystawienia dokumentu miśnieńskiego" (s. 25).

2) Niektóre warianty tekstu w części zaczerpniętej z Liber diurnus są w DM poprawniejsze niż w DH, zatem nie można zakładać, że ewentualny fałszerz, korzystający w XIII w. z DH, był w stanie poprawić tekst.

3) W partii tekstu znajdującego się wyłącznie w DM pojawiają się zapożyczenia z Dekretałów Pseudo-Izydora, a ich znajomość w kancelarii papieskiej drugiej połowy $\mathrm{X}$ w. jest ograniczona wyłącznie do notariusza Stefana, który napisał oba dokumenty. Ponieważ - zdaniem Autora - w XIII w., czyli w czasie domniemanego fałszerstwa, Pseudo-Izydor nie był już w użyciu, to „odwołanie się do Decretales w sprawie egzempcji przesądza całkowicie sprawę" na rzecz autentyczności tekstu (s. 25).

4) Zrekonstruowana przez Autora filiacja rękopisów DM ma dowodzić, że część zachowanych kopii dokumentu miśnieńskiego wywodzi się z zaginionego oryginału, podczas gdy dotąd sądzono, że wszystkie wywodzą się z widymusu powstałego w połowie XIII w.

Przeanalizujmy wedle powyższej kolejności kolejne kroki W. Jasińskiego mające argumentować za autentycznością DM.

Ad 1) Punktem wyjścia dla W. Jasińskiego jest porównanie dwóch paralelnych fragmentów obu dokumentów (wytłuszczenia pochodzą od Autora, kursywą zaznaczono partie wspólne z LD):

DH: Et ideo sancimus firmiterque consciscimus, ut post tempora prenominati abbatis fratres eiusdem monasterii in sinu suę sancte congregationis, si forte quis dignus inveniatur, abbatis eligendi liberam in perpetuum habeant potestatem. Ad hoc omnem cuiuslibet eclesię sacerdotem in prefato monasterio ditionem quamlibet habere preter sedis apostolice antistitem prohibemus ita ut, nisi ab abbate monasterii fuerit invitatus aut hospitio fortasse receptus, infra terminos ipsius monasterii nihil suo libitu ordinare aut temere exercere presumat.

DM: Et ideo in Christo sanccimus firmiterque concessimus, ut nullus metropolitanus, nullus episcopus, nulla etiam magna vel parva alterius ordinis et gradus persona preter sedis apostolice antistitem infra terminos $\mathrm{Mi}[\mathrm{s}] \mathrm{nensis}$ ecclesie, cui

\footnotetext{
${ }^{9}$ MGH DD O III, nr 186; Urkundenbuch des Hochstifts Meissen, t. I, nr 46.

${ }^{10}$ MGH DD O I, nr 447.
} 
venerabilis episcopus Burcardus preesse dinoscitur, quemquam ordinare, diiudicare, excommunicare, vel aliquid temere exercere ullo modo presumat.

Zdaniem Autora porównanie to dowodzi, że wszystkie widoczne w DM różnice wobec DH znajdują potwierdzenie w zwyczajach kancelarii Jana XIII, zatem nie mogły zostać dopisane przez fałszerza w XIII w. Dotyczy to zarówno takich dodatków, jak in Christo, zmiana formy consciscimus na concessimus, dodanie ullo modo. Zweryfikujmy te ustalenia.

W. Jasiński milcząco przyjął, że dodane w DM słowa in Christo są typowe dla X w. (może temu celowi miało służyć stwierdzenie, że to „zwrot augustiański”). Jednak gdy przyjrzymy się bliżej, widzimy, że w dokumentach papieskich z lat 986-1046 zwrot ten pojawia się wyłącznie w eschatokole (w aprekacji) bądź $\mathrm{w}$ intytulacji. Jeśli pojawia się $\mathrm{w}$ innych częściach, to wyłącznie $\mathrm{w}$ sformułowaniach rodzaju in Christo fidelibus nostris (PU nr 369 z 999 r .); noster in Christo spiritalis filius (PU nr 355 z 998 r.); susceptum in Christo sacerdotium (PU nr 354 z 998 r.). Najbliższe dokumentowi miśnieńskiemu użycie in Christo znajduje się w podfałszowanym dokumencie paliuszowym dla arcybiskupa Canterbury z 960 r. (PU nr 149): Quicquid illud fuerit adversi, virtute in Christo patientię a te devincatur. Jednak tu in Christo jest dodatkiem fałszerza z początku XII w.

Poza wyżej wskazanym fragmentem in Christo pojawia się w DM raz jeszcze (cunctis in Christo fidelibus). Podobne zwroty znajdziemy w dokumentach cesarskich, zwłaszcza z czasów Ottona III, np. cunctis nostris in Christo fidelibus (MGH DD O III, nr 235, s. 652, z 996 r.) i kilka razy in Christo fidelibus. Zwrot ten pojawia się również w kancelarii Henryka IV ${ }^{11}$ i Lotara III z Supplinburga ${ }^{12}$, czyli w czasie bliskim powstaniu kilku fałszerstw dla Miśni (o czym niżej). Nie znajdziemy podobnej formuły w papieskich dokumentach $\mathrm{X}$ w.

Użyte w DH nadzwyczaj rzadkie słowo consciscimus zostało w DM zastąpione przez powszechnie znane concessimus. W. Jasiński podkreśla, że conscisco nie pojawia się w żadnym innym dokumencie z czasów Jana XIII, natomiast concessimus jest spotykane $\mathrm{w}$ innych dokumentach Jana XIII. To prawda, ale należy dodać, że conscisco jest tak rzadkie, że w funkcji, którą pełni w DH, nie pojawia się w żadnym $\mathrm{z}$ dokumentów wydanych $\mathrm{w}$ ramach $\mathrm{MGH}$, w żadnym dokumencie papieskim wydanym przez H. Zimmermanna ani w innych dokumentach papieskich do XII w., dostępnych w innych bazach danych i wydawnictwach. Natomiast concessimus jest słowem z kolei tak powszechnie występującym w dokumentach papieskich i cesarskich tego okresu, że nie ma ono cech pozwalających powiązać je wyłącznie z kancelarią papieską i do tego konkretnie z czasami Jana XIII.

Według Autora także dodanie w DM zwrotu ullo modo (temere exercere ullo modo presumat) wskazuje na czasy Jana XIII, w którego dokumentach spotykamy te słowa. Ponownie trzeba dodać, że zwrot ullo modo presumat jest ponadczasowy i pojawia się np. w dokumentach PU nr 44 (931 r.), nr 85 (938 r.), nr †191 (rzekomo z 968 r., falsyfikat z początku XI w.). Co szczególnie istotne, zwrot ten pojawia się

${ }^{11}$ Futuris in Christo fidelibus (MGH DD H IV, nr 405); in Christo fidelibus cunctis (MGH DD H IV, nr 307).

${ }^{12}$ Cunctis Christi fidelibus (MGH DD L III, nr 32 z 1131 r.); in Christo fidelibus (tamże, nr 19, z 1129 r.). 
w 7 dokumentach Henryka IV z bardzo wąskiego okresu - lata 1066-1067. Przypomnę, że dokładnie w tym czasie osiągał szczyt spór graniczny między biskupem Miśni a metropolitą Magdeburga ${ }^{13}$. Czy w tym ostatnim przypadku można mówić o przypadkowej zbieżności? Być może z tego okresu pochodzą najstarsze warstwy fałszerstwa, które z czasem przybrały znaną nam postać DM.

Wniosek może być jedynie taki: przytoczone fakty nie dowodzą, że odmianki w DM pochodzą z tego samego czasu, co DH, gdyż są spotykane także w dokumentach wcześniejszych, późniejszych i znacznie późniejszych.

Autor przyjął w swojej analizie dwa błędne założenia. Po pierwsze, potraktował (s. 21) analizowany tekst DH jako w całości należący do formularza LD. Tymczasem tylko część wyróżniona przeze mnie italiką pochodzi z tego formularza (LD nr 86). Zatem pisarz DM także w tym analizowanym fragmencie szedł bezpośrednio za tekstem DH, tylko w niektórych miejscach go modyfikując. Po drugie, W. Jasiński zawęził zakres materiału porównawczego wyłącznie do dokumentów Jana XIII, tym samym naraził się na przeoczenie zjawisk, które występują nie tylko w dyplomatyce papieskiej z czasów tego papieża, ale w ogóle w kancelariach papieskiej i cesarskiej X-XI w. Stwierdzając, że pewne zwroty występują w dyplomach Jana XIII, uznał to za potwierdzenie autentyczności DM. W rzeczywistości niektóre z nich występują w znacznie dłuższym czasie i nie mogą być uznane za charakterystyczne wyłącznie dla praktyki kancelaryjnej Jana XIII.

W. Jasiński przeoczył wreszcie niesłychanie istotny dla oceny autentyczności DM fakt - w analizowanym fragmencie z DM znajduje się mianowicie tekst (Mi[s]nensis ecclesie, cui venerabilis episcopus Burcardus preesse dinoscitur), który pojawia się w dyplomie Ottona II z 979 r. (Misnensi ecclesiae, cui venerabilis Folcholdus episcopus praeesse dinoscitur) ${ }^{14}$. Zmieniono jedynie imiona. Chcąc ratować autentyczność dokumentu, należałoby założyć, że skryba dokumentu Ottona II znał dyplom papieski i przejął z niego ów fragment, aktualizując jedynie osobę biskupa. Jednak bardziej prawdopodobna jest przeciwna zależność - to skryba komponujący tekst DM znał dokument Ottona II. W DM znajdujemy przecież także inne miejsca wspólne z tekstem oryginalnego dyplomu Ottona III z 995 r. (MGH DD O III, nr 186), ten zaś w części opierał się właśnie na MGH DD O II, nr 184 (o czym szerzej niżej).

Ad 2) W. Jasiński uznał, że niektóre fragmenty w DM oddają tekst poprawniejszy niż paralelne miejsca w niewątpliwym autentyku DH. Twórca DM nie mógł, jego zdaniem, być zatem pracującym później fałszerzem, gdyż nie byłby w stanie poprawiać oryginalnego tekstu DH i kopiowałby nawet błędne formy.

Zdaniem W. Jasińskiego w DM, w przeciwieństwie do DH, na liście świadków mamy wymienionego na poprawnym miejscu patriarchę Akwilei. Wiadomo, że kolejność świadków na dokumentach odzwierciedlała hierarchię; o poprawności można więc mówić, jeśli testacja trzyma się tej reguły. Musimy jednak pamiętać, że w obu

${ }_{13}$ MGH DD H IV, nr 180, 183, 185, 187, 188, 189, 199.

${ }_{14}$ MGH DD O II, nr 184. Formuła episcopus - - dinoscitur lub podobna nie pojawia się w dyplomatyce papieskiej przynajmniej do połowy XI w., jest natomiast bardzo często spotykana (w identycznej lub niemal identycznej formie) w dyplomach późnych Karolingów oraz władców Niemiec, począwszy od Henryka I (np. Tuto venerabilis episcopus praeesse dinoscitur, MGH DD H I, nr 22, z 914 r.) do Ottona III, ale pojawia się również później. 
przypadkach mamy do czynienia z odpisami, a nie oryginalnymi dokumentami. $\mathrm{W}$ przypadku DH pozycja patriarchy Akwilei na liście świadków jest różna w zależności od kopii. Według jednego z dwóch głównych rękopisów Ruodaldus z Akwilei występuje po biskupie Liuzo z Cremony, w drugim - wyżej, po biskupie Antoniuszu z Brixen ${ }^{15}$. Zresztą na listach świadków innych dokumentów papieskich (poza DH i DM) patriarcha Akwilei pojawia się przez półtora wieku tylko cztery razy, wyłącznie za Jana XIII w 1. 967-968, a jego pozycja wśród świadków w tych dokumentach nie jest stała: raz staje przed metropolitą Rawenny, innym razem po nim ${ }^{16}$. Przekonujące wyjaśnienie, jak doszło do widocznych obecnie rozbieżności w liście świadków DM i DH, przyjmując, że DM jest fałszerstwem, dał już Emil von Ottenthal, którego argumentacji nie ma potrzeby tu powtarzać ${ }^{17}$.

W. Jasiński wskazuje też w DM lepsze niż w DH zapisy imion świadków. W kopii E mamy formę episcopus Verdunensis (chodzi o Verdun), która zdaniem Autora figurowała też $\mathrm{w}$ zaginionej podstawie tej kopii, bliskiej oryginałowi DM; inni kopiści (B, C, D, F) przekazali tę nazwę w postaci zniekształconej jako episcopus Verdecensis. Autor odrzucił możliwość poprawy formy na podstawie własnej erudycji kopisty, gdyż - jak zauważył (s. 16) - ten przepisywał błędne formy, nawet jeśli był w stanie je poprawić. W. Jasiński wskazuje, że błędną formę przekazała również kopia DH, gdyż tam zapisano episcopus Uerelecensis. Nie zauważył jednak, że mimo różnic w zapisie nazwy biskupstwa, wszystkie kopie (poza E, w której imię pominięto) podają zgodnie imię biskupa: Aufredus. Biskupem Verdun był wówczas Wicfried (958/9-983), zatem nie może chodzić o niego na liście świadków. Mamy zatem uzasadniony powód, by uznać, że z pewnością Aufredus w DH jest formą prawidłową. Jedynym znanym nam w ówczesnym episkopacie niemieckim i italskim Aufredusem jest Aufredus episcopus (chociaż bez wskazania siedziby) pojawiający się w prywatnym dokumencie z darowizną dla klasztoru w Arezzo z maja $958 \mathrm{r}$. Skoro identyfikacja z Wicfriedem z Verdun jest wykluczona, to formę episcopus Uerelecensis, uznaną przez W. Jasińskiego za zniekształconą z Verdunensis, da się wyprowadzić od łacińskiej nazwy Veroli (Verulum, Verulae), która miałaby na liście świadków postać Verulanensis bądź Verulensis, bardzo zbliżoną do tej z DH Uerelecensis $^{18}$. Identyfikację tę wzmacnia obserwacja, że zarówno w DM, jak i DH, Aufredus występuje wśród biskupów italskich, a nie w towarzystwie trzech biskupów zaalpejskich wymienionych $\mathrm{w}$ testacji $\mathrm{w}$ jednym miejscu ${ }^{19}$. Wszystkie zatem zapisy siedziby biskupa Aufredusa w naszych dokumentach są błędne. Zapewne dlatego,

${ }^{15}$ H. Z i m m e r m a n n, w: PU nr 186, nie odnotował istnienia tej różnicy w poszczególnych kopiach. Opieram się tu na edycji E.-D. Hehla w MGH Concilia, t. VI, cz. 2, Hannover 1987-2007, s. 292.

${ }_{16} \mathrm{PU}$ nr 177, 178, 179, 185, por. MGH Concilia VI/2, s. 292.

${ }^{17}$ E. von Ottentha1, Die Quellen der angeblichen Bulle Johann XIII. für Meißen, Mittheilungen des Instituts für Österreichische Geschichtsforschung 10, 1889, s. 614 n.

${ }_{18}$ G. S c hwartz, Die Bistümer Reichsitaliens unter den sächsischen und salischen Kaisern, Leipzig-Berlin 1913, s. 190, 277.

19 Wprawdzie biskup Spiry Otger wymieniony jest w innym miejscu, ale w dokumencie wystawionym tego samego dnia dla opata klasztoru Św. Maksymina w Trewirze (PU nr 185) w testacji wymieniono najprawdopodobniej wszystkich biskupów z Rzeszy: ultramontanis autem Theoderico Metense, Lantwardo Mindonense, Otkaro Spirense. 
że biskupstwo miało znikome znaczenie i nie było powszechnie znane. Nieprawdopodobne zatem jest, aby ewentualnie imię Wicfrieda, które miałoby się znajdować w DH i DM, uległo w trakcie przekazu tekstów obu dokumentów (niezależnie od siebie) zniekształceniu do tej samej postaci Aufredus i jednocześnie nazwa biskupstwa Verdun również miałaby ulec podobnym w obu dyplomach zniekształceniom ${ }^{20}$.

Drugi przypadek dotyczy biskupa Metzu, Teodoryka. Pojawia się on w obu dokumentach, przy czym większość przekazów ma formę Deodricus, Diodericus lub Dioctericus, a jedynie kopia E dokumentu miśnieńskiego ma zapis Theodericus, która pojawia się również w dwóch innych dokumentach Jana XIII z lat 968 i 972. Tę ostatnią uznał więc W. Jasiński za praktykowaną w tym czasie w kancelarii papieskiej, poprawną i bliższą oryginałowi (s. 17). Przeoczył niestety dokument Jana XIII wystawiony bezpośrednio dla biskupa Metzu w 970 r. (PU nr 204). Tu wielokrotnie pojawia się forma Deodericus. Wprawdzie tekst znany jest nam z insertu w Kronice świata Sigeberta z Gembloux i może odzwierciedlać lokalną praktykę zapisu imienia w XI w., ale inny dokument, wystawiony przez Benedykta VII z 976 r. (PU nr 241), imię rzeczonego biskupa przekazuje również w formie Deodericus. Nieważne, że dokument nie powstał już w kancelarii Jana XIII, o wiele ważniejsze jest to, że napisał go ten sam kancelista Stefan, który sporządził DH i miał spisać DM. Przy wskazanej różnorodności form imienia nie mamy powodu zakładać, że jedyna poprawna w danym czasie forma to Theodericus.

Analizując różnice między zwrotem auferre audeat aut alienare (DH) a auferre vel alienare audeat (DM), W. Jasiński dochodzi do wniosku, że „W pozostałych dokumentach Jana XIII wyrażenie to nigdy, poza tymi dwoma wypadkami, nie pojawia się ze słowem audeat. Zawsze w tym miejscu występuje słowo: presumat, ewentualnie pręsumpserit" (s. 22). Jednak wskazane przez niego przykłady podobnego użycie tych wyrazów nie budzą zdziwienia, gdyż należą one do formularza nr 86 z LD i będą się znajdowały w tych dokumentach, które powstawały na jego podstawie ${ }^{21}$. Skoro wiemy, że DM powstał na podstawie oryginalnego DH (a co do tego nie ma wątpliwości), to musiał przejmować cechy swego wzorca, niezależnie od tego, czy odbywałoby się to w kancelarii papieskiej, czy w warsztacie fałszerza. Jednak W. Jasiński postuluje, że forma z DM jest bardziej poprawna (chociaż jedocześnie stwierdza, że formy w obu dokumentach są poprawne), gdyż bardziej przypomina podobne zwroty z innych dokumentów Jana XIII, w których auferre vel alienare ( $\mathrm{w}$ tej kolejności) jeśli nie występuje $\mathrm{z}$ audeat, to $\mathrm{z}$ presumat. Ma to sugerować, że redaktor sporządzający tekst DM, korzystając z DH, był w stanie nawiązać do formy częściej występującej w ówczesnej kancelarii papieskiej. Nie mógłby - sądzi Autor - postąpić tak fałszerz w XIII w. Jednak zwroty w obu dokumentach w istocie różnią się przestawieniem jednego wyrazu (audeat), który to fakt z powodzeniem można przypisać ewentualnemu fałszerzowi przepisującemu tę część

${ }^{20} \mathrm{Na}$ liście świadków obu dokumentów znajduje się inna pomyłka: Efemarius Antias chodzi o biskupa Ankony, której łacińska nazwa uległa zniekształceniu (powinno być Anconitanus). W tym przypadku jednak imię jest prawidłowe w obu przekazach.

${ }^{21}$ Dokumenty papieskie napisane według LD nr 86 zestawił M. R a th s a c k, Die Fuldaer Fälschungen: Eine rechtshistorische Analyse der päpstlichen Privilegien des Klosters Fulda von 751 bis ca. 1158, Stuttgart 1999, s. 90. 
$\mathrm{z} \mathrm{DH}{ }^{22}$. Zresztą zwrot auferre vel/aut alienare występuje w dokumentach papieskich nawet w drugiej połowie XI w. ${ }^{23}$ oraz w kilku dokumentach Henryk IV z lat 1065-106724.

Ad 3) Zdaniem W. Jasińskiego autentyczności DM dowodzi obecność w nim zapożyczeń z Pseudo-Izydora, gdyż działający w XIII w. fałszerz nie miałby okazji, aby nawiązać do tekstu pseudoizydoriańskiego, który - w opinii Autora - nie był już wtedy używany. W tej ostatniej sprawie się myli, gdyż szczyt produkcji rękopisów z tekstem Pseudo-Izydora, a tym samym szczególne zainteresowanie tym dziełem, przypada dopiero na XII w. Myli się też z innego powodu: mianowicie pseudoizydoriański passus z DM został przejęty przez kilka kolekcji kanonistycznych od końca IX w. po Dekrety Gracjana z ok. 1140 r., a to ostatnie dzieło stało się rychło najbardziej popularnym zbiorem prawa kanonicznego i mogło stać się źródłem pośrednich zapożyczeń w XIII w. Nawet jeśli do fałszerstwa doszło wcześniej (o czym niżej), to zauważmy, że dokładnie te właśnie fragmenty Pseudo-Izydora były recypowane w innych kolekcjach kanonicznych - jak np. Collectio Anselmo dedicata (jeden z najbardziej popularnych zbiorów prawnych w X w., którego popularność nie wygasła w następnym stuleciu) - oraz Dekrety Burkharda z Wormacji z początku XI w. (jeden z najpopularniejszych zbiorów prawa kanonicznego w Niemczech w XI i XII w.) ${ }^{25}$. Zatem działający po połowie X w. fałszerz miał szereg źródeł, z których mógł zapożyczyć wspomniany cytat z Pseudo-Izydora, nie odwołując się bezpośrednio do tego dzieła.

Dowody na znajomość Pseudo-Izydora przez notariusza Stefana, który sporządził DH i miałby być autorem DM, szczególnie uwypuklone przez Horsta Fuhrmanna, są w rzeczywistości o wiele bardziej ograniczone, niż sądził niemiecki historyk, a za nim Autor. W sporządzonym przez Stefana dokumencie erekcyjnym metropolii magdeburskiej z 967 r. (PU nr 177) można jedynie mówić o wpływie pseudoizydoriańskich wyobrażeń o strukturze Kościoła (według rzekomego listu papieża Klemensa I). Nie ma tu natomiast zapożyczeń tekstowych ${ }^{26}$. Dosłowny cytat z Pseudo-Izydora

${ }^{22}$ Teksty obu dokumentów, jak i różnych kopii DM, różnią się kolejnością słów także $\mathrm{w}$ innych miejscach, $\mathrm{np}$.: dignitatis sit - sit dignitatis; hoc apostolico - apostolico hoc. Do dziś zamiana kolejności słów jest jednym z najczęstszych błędów przy przepisywaniu tekstu.

${ }^{23} \mathrm{~Np}$. Acta Pontificum Romanorum inedita, t. III, wyd. J. Pflugk-Hartung, Stuttgart 1886, nr 10, s. 10; o możliwej przypadkowości dowodzi pojawienie się tego zwrotu w liście Matyldy z Tusculum z 1115 r. (MGH, Die Urkunden und Briefe der Markgräfin Mathilde von Tuszien, wyd. E. Goez, W. Goez, Hannover 1998, nr 139).

${ }^{24} \mathrm{~Np}$. MGH DD H IV, nr 165 (1065 r., auferre alienare), 180 (1066 r., auferre alienare ullo modo presumat).

${ }_{25}$ Burchard, Decretorum libri viginti, I, 66, Patrologiae Latinae cursus completus, wyd. J. P. Migne, t. 140, Paris 1853, kol. 565: Nullus autem primas vel metropolitanus dioecesanam ecclesiam vel parochianum, aut aliquid de eius parochiae, praesumit excommunicare, vel diiudicare aliquid; podobny zwrot w Decretum, I 143, tamże, kol. 591; por. H. H o f f m a n n, R. P o k o r n y, Das Dekret des Bischofs Burchard von Worms. Textstufen - Frühe Verbreitung - Quellen, München 1991, s. 248, 272.

${ }_{26}$ Nie wszystkie argumenty H. F u h r m a n n a, Einfluß und Verbreitung der pseudoisidorischen Fälschungen. Von ihrem Auftauchen bis in die neuere Zeit, t. I, Stuttgart 1973, s. 318, można dziś uznać za trafne. Np. traktowany przez H. Fuhrmanna jako pseudoizydoriański zwrot ad Germaniam na określenie tej części Europy był już prawdopodobnie w użyciu niezależnie. Według autora pierwszego Żywota św. Wojciecha miejscem narodzenia świętego 
zawiera przywilej wynoszący arcybiskupa Trewiru do godności prymasa z 22 I 969 r. (PU nr †195). W. Jasiński nie bierze jednak pod uwagę, że ów dokument w najlepszym wypadku można uznać za podfałszowany. Wprawdzie H. Fuhrmann ${ }^{27}$ sądzi, iż oparty jest na prawdziwym rdzeniu, ale wedle innych badaczy (H. Zimmermann, H. Beumann, M. Rathsack) mamy do czynienia z całkowitym fałszerstwem ${ }^{28}$. Jeślibyśmy nawet przyjęli tu dyktat odbiorcy, jak sądzi Egon Boshof ${ }^{29}$, to odzwierciedla to znajomość Pseudo-Izydora w Trewirze w X w., co jest potwierdzone innymi źródłami, a nie w Rzymie ${ }^{30}$. Wedle Mogensa Rathsacka fałszerstwo to miano sprokurować $\mathrm{w}$ drugiej dekadzie XI w. ${ }^{31} \mathrm{Z}$ niekwestionowanym dosłownym cytatem z Pseudo-Izydora spotykamy się w dokumencie papieskim z 981 r., znoszącym biskupstwo w Merseburgu (PU nr 270) 32. Wprawdzie nieco wcześniej, w dokumencie Benedykta VII dla biskupa Elne w Hiszpanii z 979 r. (PU nr 252), jako wzorzec dla partii końcowej dokumentu (sankcja i koroboracja) wykorzystano Constitutum Constantini, które powiązane jest z kolekcją pseudoizydoriańską, ale dzieło to rozchodziło się niezależnie od Dekretałów Pseudo-Izydora. W przypadku tego dokumentu nie możemy wykluczyć, że w całości mamy do czynienia z dyktatem odbiorcy, gdyż w datacji spotykamy specyficzny system przyjęty w Hiszpanii, nieznany natomiast w kancelarii papieskiej. Zatem i ten dokument poświadcza raczej znajomość tekstu Pseudo-Izydora w Hiszpanii, a nie przez notariusza Stefana ${ }^{33}$.

Zauważmy, że te nawiązania do Pseudo-Izydora w dyplomatyce papieskiej, które możemy uznać za pewne, pochodzą wprawdzie z dokumentów zredagowanych przez Stefana, ale oddają one postanowienia synodów. W takim razie trudno uznać, że wprowadził je wyłącznie kancelista Stefan. Teksty tych dokumentów oddają raczej argumentację obecnych na synodach biskupów. Mamy inne przykłady, gdy ojcowie synodalni w X w. wprowadzali argumentację zdradzającą znajomość Pseudo-Izydora. Tak było podczas synodu w Bazylei w 991 r. ${ }^{34}$, a w dokumencie Grzegorza V z 997 r., w którym papież informuje arcybiskupa mogunckiego o postanowieniach synodu w Pawii, mamy odwołanie się do pseudoizydoriańskich dekretów papieża Juliusza ${ }^{35}$.

było locus in partibus Germanie (Monumenta Poloniae Historica, series nova, t. IV, cz. 1, wyd. J. Karwasińska, Warszawa 1962, s. 3).

${ }^{27}$ H. F u hrm a n n, Einfluß, t. II, s. 319.

${ }^{28}$ W konsekwencji dwa kolejne dokumenty napisane przez Stefana (PU nr $\dagger 222, \uparrow 235$ ), datowane na 973 i 975 r., są zdaniem M. Rathsacka fałszerstwami z tego samego okresu.

${ }^{29}$ E. B o s h of, Das Erzstift Trier, Köln 1972, s. 49 n.

${ }^{30}$ E. B o s h o f, Köln, Mainz, Trier. Die Auseinandersetzung um die Spitzenstellung im deutschen Episkopat in ottonisch-salischer Zeit, Jahrbuch des Kölner Geschichtsverein 49, 1978, s. 19-48, tu s. 27 n.

${ }^{31}$ M. R a t h s a c k, Die Fuldaer Fälschungen: Eine rechtshistorische Analyse der päpstlichen Privilegien des Klosters Fulda von 751 bis ca. 1158, Stuttgart 1999, s. 277-297.

32 Por. MGH Concilia, t. VI/2, s. 368 n.

${ }^{33}$ H. F u h r m a n n, Einfluß, t. I, s. 228; t. II, s. 404 n.; szerzej t e n ż e, Konstantinische Schenkung und abendländisches Kaisertum, Deutsches Archiv für Erforschung des Mittelalters 22, 1966, s. $172 \mathrm{n}$.

${ }^{34}$ MGH Concilia, t. VI/2, s. $380 \mathrm{n}$.

${ }_{35} \mathrm{PU}$ nr 341: Auctoritate enim Julii papę sancitum est, qui etiam orientales episcopos ad sinodum venire spernentes depositionis reos iudicavit, illos vero absque apostolica auctoritate depositos innocentes remanere. 
W innym miejscu mamy powołanie się na pochodzący z tego samego źródła tzw. synod papieża Symmacha i tu dodany został dokładny cytat.

Znamy również wcześniejsze cytaty z Pseudo-Izydora w dyplomatyce papieskiej. W dokumencie z 944 r. dla biskupstwa w Kapui papież Marinus II powołał się na pseudoizydoriański tekst papieża Celestyna, wraz z cytatem (PU nr 100). W 955 r. na pseudoizydoriańską tradycję powołał się Jan II (PU nr 137).

Wykorzystanie Pseudo-Izydora w fałszerstwie powstałym na terenie Rzeszy było jak najbardziej możliwe, nawet już w X w. Dowodzi tego jeden z dokumentów sfałszowanych przez biskupa Pilgrima z Pasawy w latach siedemdziesiątych tego stulecia; mamy tam w kilku miejscach nawet dokładne pseudoizydoriańskie cytaty (PU nr $\dagger 87$, s. 152). Zagrożony staraniami Pilgrima arcybiskup salzburski Fryderyk nie pozostał dłużny i sam sprokurował rzekomy dokument Benedykta VI, w którym też powoływał się na pseudoizydoriańskie argumenty (PU nr †224).

Ad 4) Przeprowadzona po raz pierwszy przez W. Jasińskiego tak dokładna analiza zależności między kopiami DM doprowadziła go do nowych wniosków. Autor dowodzi przede wszystkim, że mamy dwie grupy rękopisów sięgające do zaginionego oryginału - a nie, jak dotąd przyjmowano, że wszystkie kopie pochodzą od spreparowanego w pierwszej połowie XIII w. fałszerstwa ${ }^{36}$. Według W. Jasińskiego do pierwszej grupy kopii należy widymus z 1250 r. (B) i kopia E (w wersjach $\mathrm{E}_{1}$ i $\left.E_{2}\right)^{37}$. Oba przekazy nie pochodzą wprawdzie - zdaniem Autora - bezpośrednio

36 Jedynie H. Zimmermann (PU s. 368) był zdania, że istniał wprawdzie oryginalny dokument Jana XIII z początku 968 r. dla nowo założonego biskupstwa w Miśni, ale został zniszczony tuż przed $1250 \mathrm{r}$., po spreparowaniu podfałszowanej wersji.

${ }^{37}$ Dzięki uprzejmości W. Jasińskiego (za co mu serdecznie dziękuję) mogłem obejrzeć ksero rękopisu E. Moje obserwacje nie pokrywają się z wnioskami Autora. Przede wszystkim nie widzę powodu, żeby wydzielać osobne kopie $\mathrm{E}_{1} \mathrm{i} \mathrm{E}_{2}$. Wprawdzie rękopis może sprawiać wrażenie, że powstał, jak przedstawił to W. Jasiński, jako odpis z dwóch różnych kopii, ale są fakty, które temu przeczą. Gdyby było tak, że wzorzec dla $\mathrm{E}_{1}$ miał trwale uszkodzony (np. obcięty czy z innego powodu zupełnie nieczytelny) prawy margines z częścią tekstu, a te braki były później uzupełnione na podstawie innego przekazu $\left(\mathrm{E}_{2}\right)$, to niewyjaśnione pozostają miejsca, które pierwszy kopista pozostawił puste w innych częściach tekstu, zaznaczając je wykropkowaniem. Dopiero ta sama ręka, która naniosła większość uzupełnień na prawym marginesie, wprowadziła poprawki w pozostałych brakujących fragmentach tekstu. Tak jest np. karcie 1 wiersz 3, k. 2 w. 10-11 czy k. 3 w. ostatni. Ponadto na k. 1 w. 17-18 został przepisany pierwszą ręką tekst do samego końca $\mathrm{i}$ jest to tekst ciągły na dwa wiersze, zatem w tej części podstawa musiała być czytelna na całej szerokości. Wprawdzie ta sama ręka jeden z tych wierszy przekreśliła i wpisała (częściowo w postaci glosy marginalnej) ponownie, ale ilość tekstu wskazuje, że nie było tu problemu z odczytem pierwotnie całych dwóch wierszy. Kopiowany tekst nie mógł być zatem przycięty na prawym marginesie. Pozostawione puste miejsca, które nie zostały uzupełnione (np. k. 3 z początkiem tekstu dyplomu Innocentego II), mogły być już mniej interesujące, więc nie zadawano sobie trudu $\mathrm{z}$ ich rekonstrukcją. Nie została uzupełniona także testacja w DM, gdyż było to dla kopisty mniej interesujące, dopisano jedynie starannie datację, znajdującą się na prawym marginesie podstawy. Być może prawy margines był nieczytelny (np. poplamiony, wyblakły?) dla skryby pierwszej ręki i dopiero inny skryba, może o lepszych oczach lub pracujący w lepszych warunkach, odczytał i dopisał brakujące fragmenty, ale opierał się na tej samej podstawie. Dalej więc w tekście konsekwentnie piszę o jednej kopii E. Ponieważ $\mathrm{w}$ sposób pośredni pochodzi ona $\mathrm{z}$ widymusu, o czym świadczy przepisanie jego formuł, sądzę, że rację miał H. Zimmermann, nie uwzględniając 
od oryginału, lecz od wspólnego dla nich wzorca $\left(\mathrm{B}_{+}\right)$, $\mathrm{z}$ tym że $\mathrm{E}_{1}$ oraz $\mathrm{E}_{2}$ przez dodatkowe pośrednictwo drugiej ekspedycji widymusu $\left(\mathrm{B}_{\mathrm{E}}\right)$. Druga grupa składa się z trzech rękopisów (F, C, D), które zawierają późniejsze interpolacje, wprowadzone na podstawie dokumentów Ottona II i Ottona III. Przekazy te tworzą jedną grupę, dla której wzorcem jest kopia F, a od niego wywodzi się kopia C, z niej zaś - D. Zdaniem W. Jasińskiego, grupa ta nie wywodzi się ze wspomnianego widymusu, ale sięga wprost oryginału, poszerzonego o interpolacje. Autor wyciągnął stąd wniosek, że rodzina kopii F, C, D była w części formularzowej bliższa DH niż kopie B i E. Gdyby nawet ustalenia te były trafne, to nie przesądzają o tym, że wspólny tekst dla obu grup był tekstem oryginalnym - obie grupy mogą równie dobrze wywodzić się od falsyfikatu.

Przedstawione porównania nie są przekonujące. Zestawienie odmianek na s. 15 sugeruje taki podział, ale nie jest on kompletny. Jeśli uzupełnimy je o nieuwzględnione przez Autora lekcje z kopii F, to okaże się, że np. forma Nizizi, mająca być charakterystyczna dla grupy $\mathrm{B}, \mathrm{E}$, pojawia się również $\mathrm{w} \mathrm{F}$, podobnie diiudicare jest w B, E oraz F, a nazwa Castrenensis pada w B oraz F. Widzimy zatem, że sugerowane przez Autora jednoznaczne rozgraniczenie na dwie gałęzie przekazu okazuje się dość słabo uzasadnione.

W mojej opinii wszystkie te różnice między kopiami DM są tak mało charakterystyczne, że możemy je przypisać błędom podczas kopiowania wspólnego dla wszystkich wzorca - rzekomego oryginału DM. Z niego wywodzi się ta gałąź przekazu, którą znamy z widymusu (kopie B i E). W którym momencie powstała wersja interpolowana, znana nam jedynie z kopii F, C i D, trudno ocenić. Ponieważ zarówno tekst widymowany, odzwierciedlający rzekomy oryginał, jak i interpolacje opierają się na tym samym zestawie dokumentów ottońskich, sądzę więc, że oba musiały powstać w bliskim związku ze sobą. Zatem tekst ,interpolowany” reprezentuje jedną $\mathrm{z}$ redakcji (obszerniejszą) przygotowywanego fałszerstwa i w tej postaci dostał się do późnośredniowiecznych i nowożytnych kopiariuszy. Jej najstarsza wersja (F) znana jest z zaginionej kopii datowanej przez wydawcę na XIII w. Trzeba podkreślić, że analiza relacji między rękopisami nic nie wnosi do kwestii autentyczności DM.

W. Jasiński dostrzega, że w miejscu, gdzie w DH mamy wyrażenie: ne qua parva magnave persona sibi licere, w DM pojawia się zwrot: ne quis mortalium sibi licere. Uznaje, że ten drugi został przejęty za kodyfikacjami rzymskimi (Kodeks Teodozjusza 16.10.9; Kodeks Justyniana I.11.2), gdyż w piśmiennictwie epoki pojawia się bardzo rzadko. Sądzi, że w X w. prawo rzymskie mogło być znane w Italii. W rzeczywistości w cytowanych przez Autora ustępach kodyfikacji późnoantycznych znajdujemy tylko zwrot: ne quis mortalium ${ }^{38}$, który sam w sobie nie jest wystarczająco charakterystyczny. Ponadto kontekst prawny nie nawiązuje do sytuacji z dokumentu miśnieńskiego czy jakiegokolwiek innego, w którym się słowa

tej kopii w swym wydaniu. W. Jasiński uważa wprawdzie, że kopia E oddaje tekst najbliższy oryginałowi, gdyż posiada poprawniejsze zapisy w testacji, ale wykazałem już wyżej, iż nie jest to zasadny wniosek.

38 Theodosiani libri XVI cum constitutionibus Sirmondianis et leges novellae ad Theodosianum pertinentes, wyd. Th. Mommsen, P. Meyer, Berlin 1905, t. I, cz. 2, s. 899; Codex Iustinianus, wyd. P. Krüger, Berlin 1877, s. 94. 
te pojawiają (np. falsyfikat rzekomo wystawiony przez Ottona I w 900 r.: MGH DD $\mathrm{O}$ I, nr 435). W dokumentach z X i XI w. słowo mortalis pojawia się wprawdzie nie w tym samym zwrocie co w DM, ale w tej samej funkcji znaczeniowej (np. nulli mortalium - MGH DD O III, nr 26 z 985 r.; MGH DD K II, nr 16 z 1025 r.; MGH DD H IV, nr 334 z 1081 r.). W dokumentach papieskich mortalis w podobnej funkcji pojawia się dopiero od początku XI w., za Benedykta VIII (PU nr 502, 503, 523, 527). W późniejszym okresie pojawia się również bardzo rzadko.

Dlaczego zatem formularzowy zwrot ne qua parva magnave persona zastąpiono ne quis mortalium? Zauważmy, że owi mortales pojawiają się w DM w ustępach wzorowanych - o czym niżej - na dokumentach cesarskich MGH DD O II, nr 184 (z 983 r.) ${ }^{39}$, oraz O III, nr 186 (z 995 r.) $)^{40}$. Jeżeli tym właśnie miał sugerować się redaktor DM, dokonując zmian wobec $\mathrm{DH}$, wskazuje to na późniejsze powstanie a więc na fałszerstwo.

III.

Do dyskusji nad autentycznością DM warto wprowadzić kolejne argumenty, nieuwzględnione przez Autora.

Papieskiemu przywilejowi dla Hersfeldu towarzyszyły dwa niemal równobrzmiące przywileje wystawione tego samego dnia - 15 II 968 r. - w Benewencie przez Ottona I i jego syna ${ }^{41}$. Wprawdzie nie ma w nich bezpośredniego odwołania do przywileju Jana XIII, ale widać tam jeden passus, który może być zapożyczony z dokumentu papieskiego: situm iuxta flumen cui nomen est Fulda in pago Hassaie. W przypadku DM nie mamy towarzyszących mu przywilejów cesarskich dla klasztoru w Miśni, chociaż zachowały się inne cesarskie dyplomy dla Miśni z tego okresu. Nie jest to argument jednoznaczny i może być traktowany wyłącznie jako dodatkowa poszlaka, gdyż np. wydany tego samego dnia dokument Jana XIII dla ottońskiej fundacji w Gandersheim (PU nr 184) również nie ma odpowiednika w dyplomie cesarskim (a przynajmniej taki się nie zachował).

Kolejną kwestią jest ewentualna zgodność treści DM z innymi danymi historycznymi. DM jest jedynym źródłem, w którym znajduje się wzmianka o klasztorze pod wezwaniem św. Jana Ewangelisty w Miśni. Fakt ten był jednym z argumentów wykorzystywanych przez krytyków autentyczności DM. Natomiast K. Uhlirz uznał, że jest wręcz przeciwnie. Wzmianka ta ma przemawiać za autentycznością, gdyż fałszerzowi trudno byłoby wymyślić istnienie klasztoru, który w jego czasach już nie istniał. Według niego w Miśni mógł zatem rzeczywiście funkcjonować klasztor starszy niż biskupstwo. Jako ewentualne analogie K. Uhlirz wskazał, że także w Merseburgu i Żytycach mamy wczesne poświadczenia funkcjonowania klasztorów, być może poprzedzających powstanie biskupstw ${ }^{42}$. Są to jednak analogie, moim zdaniem,

39 omnium utilitatum quibus mortales utuntur.

40 insuper tota utilitate et in omnibus rebus quibus mortales utuntur diversis modis.

${ }^{41}$ MGH DD O I, nr 356; O II, nr 17.

${ }^{42}$ K. Uhlirz, Zur Beurtheilung der Bulle Johannes XIII. für Meissen, Mittheilungen des Instituts für Österreichische Geschichtsforschung 16, 1895, s. 515 n. Chodzi o MGH DD O II, nr 161, 162 (Merseburg, 977 r.) oraz MGH DD O III, nr 163 (Żytyce, 995 r.). 
niezbyt przekonujące. Początki grodów w Merseburgu i Żytycach sięgały okresu późnokarolińskiego i były one ważnymi ośrodkami władzy za dynastii saskiej. Natomiast Miśnia była zupełnie nowym nabytkiem (saski gród założono dopiero w 929 r. i nie był on kontynuacją wcześniejszego grodu słowiańskiego), a cały region można było uznać za trwale poddany władzy ottońskiej dopiero po sukcesach margrabiego Gerona w 963 r. Prędzej można zakładać, że w grodzie postawiono wówczas kościół pod wezwaniem św. Jana Ewangelisty dla obsługi saskiej obsady grodu, ale ciągle był to teren nieustannych walk. Jeszcze w 1015 r. biskup Miśni Eiko kazał się pochować w rodzinnych stronach, gdyż bał się, że w samej Miśni nie znajdzie spokoju po śmierci ${ }^{43}$. Patrocinium św. Jana Ewangelisty katedry miśnieńskiej pojawia się obok św. Donata męczennika tylko w dwóch późniejszych autentycznych dokumentach (MGH DD O II, nr 184, z 983 r.; MGH DD O III, nr 183, z 995 r.) oraz powstałych na bazie pierwszego z nich dwóch falsyfikatach (MGH DD O III, nr 186; MGH DD $\mathrm{H} \mathrm{IV}$, nr 275) i w trzecim fałszerstwie powstałym m.in. na podstawie pierwszego z dwóch wcześniej wymienionych (MGH DD O I, nr 449). W pozostałych autentykach dla Miśni wymieniony jest tylko św. Donat jako jedyny patron katedry. Wezwanie św. Jana Ewangelisty mogło pochodzić od wcześniejszego kościoła poprzedzającego katedrę biskupią i zostało w końcu X w. wyparte przez nowsze patrocinium. Być może jakąś reminiscencją realiów z 968 r. jest informacja w fałszywym dyplomie Ottona I rzekomo z 948 r., dotyczącym fundacji biskupstwa w Miśni: ecclesiam quondam in Misna civitate collocari et construi praecepimus - - in honore sancti Iohannis ęvangelsistę sedem episcopalem fieri decrevimus ${ }^{44}$. Ponieważ dokument MGH DD O III, nr 186 stanowił podstawę późniejszych fałszerstw, w tym dla DM, nic zatem dziwnego, że podwójne patrocinium znajdujemy w dwunastowiecznych falsyfikatach miśnieńskich ${ }^{45}$.

Istnieje jeszcze wątpliwość natury prawno-kanonicznej. Gdyby DM był autentykiem, to zupełnie nie miałoby sensu egzymowanie klasztoru (czyli wyłączenie go spod jurysdykcji miejscowego biskupa), który miał być mocą tego samego dokumentu podstawą tworzonego jednocześnie biskupstwa, tym bardziej że w danym momencie na czele obu instytucji i tak miała stać jedna osoba, a cechą klasztorów przykatedralnych była właśnie unia personalna opata i biskupa. Klasztory przykatedralne nigdy nie były (przynajmniej w tym czasie) wyłączane spod jurysdykcji biskupa - nie miałoby to przecież sensu ${ }^{46}$. Widzimy, że funkcjonowanie klasztoru w Miśni przed 968 r. jest dość wątpliwe, zwłaszcza że jedyne źródło potwierdzające jego istnienie to DM.

${ }^{43}$ W. S c hle s inger, Kichengeschichte Sachsens im Mittelalter, t. I, Köln-Graz 1962, s. $33 \mathrm{n}$.

${ }^{44}$ MGH DD O I, nr 437. Warto zauważyć, że pierwsza znana nam instytucja kościelna w Miśni (poza biskupstwem) powstała dopiero w 1114 r. (W. S c h le s in ge r, Verfassung und Wirtschaft des mittelalterlichen Bistums Meißen, w: Das Hochstift Meißen. Aufsätze zur sächsischen Kirchengeschichte, Berlin 1973, s. 39 n.).

${ }^{45}$ Podwójne patrocinium pojawia się w falsyfikatach z początku XII w. (MGH DD H IV, nr 275; MGH DD O I, nr 449).

${ }^{46}$ Chyba trafnie zauważył M. R a th s a c k, Die Fuldaer Fälschungen, s. 84 n., że trudno widzieć $\mathrm{w}$ dokumencie dla Hersfeldu nadanie przywileju egzempcji, gdyż ta nie jest znana dość licznym późniejszym dokumentom hersfeldzkim aż do XIII w., kiedy to dopiero klasztor uzyskał taki status. 
IV.

Najpoważniejszym błędem w analizie przeprowadzonej przez W. Jasińskiego jest zupełne pominięcie sprawy zależności DM od kilku późniejszych dokumentów cesarskich (nie odnoszę się tu do oczywistych dwóch interpolacji znanych z rodziny rękopisów F, C i D). Przede wszystkim chodzi o obszerny ustęp (od More antiquorum imperatorum do reforant et reddant), zawierający w całości fragment z przygotowanego w kancelarii cesarskiej gotowego dokumentu (MGH DD O III, nr 186) z 995 r., który w ostateczności nie został opieczętowany ${ }^{47}$. Dopiero później przewieszono do niego oryginalną pieczęć odjętą z jakiegoś innego dokumentu (prawdopodobnie MGH DD O III, nr 183). Być może powodem wstrzymania ekspedycji w kancelarii było podjęcie już restytucji zlikwidowanego w 981 r. biskupstwa merseburskiego, chociaż w literaturze zamysł restytucji datuje się dopiero na 997 r. ${ }^{48}$ Potwierdzenie wówczas granic biskupstwa Miśni, które terytorialnie wzbogaciło się na likwidacji biskupstwa w Merseburgu, utrudniałoby planowane wznowienie biskupstwa w Merseburgu w starych granicach.

Obrońcy autentyczności DM w całej jego rozciągłości - a do tych zalicza się W. Jasiński - muszą zakładać, że tekst w dokumencie ottońskim został przejęty z dokumentu miśnieńskiego, a nie odwrotnie. Tej kwestii Autor jednak w ogóle nie porusza. Analiza obu dokumentów prowadzi do wniosku, że to dyplom cesarski był wzorcem, a nie odwrotnie - przede wszystkim dlatego, że interesujący nas fragment tekstu powstał dzięki kilku zapożyczeniom z wcześniejszego autentycznego dyplomu Ottona II z 27 II 983 r. (MGH DD O II, nr 184). Musielibyśmy zatem założyć, że oba dokumenty powstały na podstawie tekstu DM.

W niżej cytowanym fragmencie z DM zapożyczenia z dokumentu MGH DD O III, nr 186 zaznaczono kursywą, a przejątki z MGH DD O II, nr 184 wytłuszczono:

More antiquorum imperatorum hii duo imperatores, pater et filius, nobis assidentes Misnensi episcopatui terminum inposuerunt nominando fines et determinationes locorum, sicut infra tenetur: Ubi caput et fons et aque que dicitur Odera inde quasi inde quasi [!] recta via usque ad caput Albie, inde deorsum in occidentalem partem, ubi divisio duarum regionum est Behem et Nisen, ibidem ultra Albiam et per silvam in occidentalem partem usque ad caput Milde et sic deorsum per ambas plagas eiusdem fluminis ${ }^{49}$ usque dum Miltam intrat in Albiam ${ }^{50}$ et sic sursum et ultra provinciam Nizizi ad ipsum terminum sine dubio necnon in altera parte Luzice et

${ }^{47}$ Datacja błędnie podaje 996 r. O dokumencie szerzej Th. Kölzer, Th. Ludwi g, Das Diplom Ottos III. für Meißen, w: Europas Mitte um 1000. Katalog und Handbuch zur Ausstellung, t. II, Stuttgart 2000, s. 764-766; J. P e t e r s o h n, König Otto III. und die Slawen an Ostsee, Oder und Elbe um das Jahr 995. Mecklenburgzug, Slavnikidenmassaker, Meißenprivileg, Frühmittelalterliche Studien 37, 2003, s. 99-139, tu s. 113 n.

48 Por. D. A. S i k o r s k i, Kościół w Polsce za Mieszka I i Bolesława Chrobrego, Poznań 2011, s. 335 n. Za przesunięciem początków myśli o restytucji Merseburga na 995 r. argumentuje Th. L udwi g, Die Urkunden, s. 262.

49 W tym miejscu MGH DD O III, nr 186, zawiera jeszcze słowa: scilicet prope occidentalem ripam Rochilinze, które nie zostały przejęte do DM.

${ }_{50} \mathrm{Tu}$ w DM (kopie F, C, D) następuje interpolacja: necnon ob hoc diximus in occidentali plaga, quia multe ville pertinent ad orientales urbes infra eundem terminum. 
Selpoli et sic usque ad civitatem Sulpize, illam videlicet infra eundem terminum et inde in aquam que dicitur Odera et sic Odera sursum usque ad caput eius. Omnes vero, quemadmodum hii presentes imperatores statuisse fatentur, qui infra terminum istum habitant, in omni fertilitate terre, frugum et pecudum, in argento, vestimento necnon quod Teutonici dicunt oborcoufunga et talunga familiarum, insuper tota utilitate et in omnibus rebus, quibus mortales utuntur in diversis modis, decimationes, quas Deo cuncta gubernanti debent ad Misnensem ecclesiam, primo Deo, deinde sancto Johanni Ewangeliste universa dubietate procul remota persolvant, reforant et reddant.

Jeśli tekst z DM miałby być pierwotny, to trzeba by uznać, że w 983 r. wyciągnięto $\mathrm{z}$ niego tylko zaznaczone pogrubionym drukiem fragmenty, a w dyplomie z 995 r. - już całość. Jednak dokument z 983 r. nie dotyczył granic biskupstwa, lecz darowizny Ottona II na rzecz biskupstwa pewnego majątku, cła na Łabie i dziesięcin z jednego z okręgów grodowych (burgwardu), więc ewentualne przejątki z DM wyglądałyby tu dziwacznie, gdyż są w części mało znaczące dla treści i wybiórcze. Do sporządzenia tego tekstu niepotrzebne było odwoływanie się do ewentualnego przywileju Jana XIII po to, żeby przejąć kilka nieistotnych dla treści fraz.

Po drugie, gdyby dokument MGH DD O III, nr 186 miał nawiązywać do wcześniejszych przywilejów, to raczej powinna się tu znaleźć wzmianka o poprzednikach. W dokumencie Ottona III nie ma powołania się nie tylko na dokument Jana XIII ${ }^{51}$, ale przede wszystkim na wynikające z tekstu DM rozporządzenia poprzednich cesarzy. W dokumencie z 995 r. przywołany jest jedynie Otto II (pro remedio animarum - - patris nostri) - prawdopodobnie dlatego, że Otto III w części potwierdzał jego nadania (MGH DD O II, nr 184).

Jeżeli porównamy obie części wspólne DM i dokumentu z 995 r. (wytłuszczone), to bardziej prawdopodobna jawi się zależność DM od dyplomu cesarskiego.

MGH DD O III, nr 186: pro remedio animarum dilecti avi nostri simul et patris nostri nec non pro nostrae anime remedio more antiquorum imperatorum et regum nostra regali potestate Misnensi episcopatui terminum posuimus nominando fines et determinationes locorum sicut infra tenetur (dalej następuje opis granic).

DM: interponentes tamen ea, que et ipsi principes nostri in nostris privilegiis cupiunt exponi et cunctis in Christo fidelibus manifesta fieri. More antiquorum imperatorum hii duo imperatores, pater et filius, nobis assidentes Misnensi episcopatui terminum inposuerunt nominando fines et determinationes locorum, sicut infra tenetur (dalej następuje opis granic).

Otto III, przywołując swoich cesarskich poprzedników, mógł mieć na myśli dwa wcześniejsze dyplomy z nadaniami na rzecz biskupstwa w Miśni: wydane przez Ottona I w 971 (MGH DD O I, nr 406) i przez Ottona II w 983 r. (MGH DD O II, $\mathrm{nr}$ 184). Nie wiadomo natomiast, do czego miałby się odnosić zwrot more antiquorum imperatorum w DM.

${ }^{51}$ Sam brak powołania się na dokument papieski nie jest oczywiście rozstrzygający, gdyż np. przywilej papieski dla Hersfeldu również nie został wspomniany w odpowiednim dokumencie cesarskim, z niemal identycznym rozporządzeniem (MGH DD O II, nr 356, z 15 II 968 r.). 
Odpowiedni ustęp DM można wyprowadzić z tekstu dokumentu Ottona III, natomiast trudno sobie wyobrazić sytuację odwrotną. Można zrozumieć, że pisarz DM, mając przed sobą słowa more antiquorum imperatorum et regum et nostra regali potestate, skrócił je o słowa użyte w pierwszej osobie (nostra regali potestate) ${ }^{52}$, które w dokumencie wystawionym przez papieża zgoła nie pasowały. Trudniej byłoby wyjaśnić, dlaczego pierwotną wersję DM miano by rozszerzyć o ten passus w dokumencie Ottona ${ }^{53}$.

Dla podsumowania tej części można przypomnieć, że tego samego dnia ci sami biskupi, którzy widymowali DM, wystawili też widymus oczywistego falsyfikatu, jakim jest zachowany w rzekomym oryginale fałszywy dokument fundacyjny biskupstwa miśnieńskiego z 948 r. (MGH DD O I, nr 449), który zawiera opis granic przejęty z dokumentu O III, nr 186. W oczach biskupów zgodność opisu granic przemawiała pewnie za autentycznością obu dyplomów.

V.

Kolejnym błędem W. Jasińskiego jest analiza dokumentu bez uwzględnienia kontekstu, w którym funkcjonował. Przywiązując się do bronionej tezy o autentyczności dokumentu, nie próbował rozważyć podważających ją argumentów. Dwustuletnie doświadczenia dyplomatyki uczy, że jeśli w jakimś środowisku prokurowano fałszerstwa w pewnym konkretnym celu, to należy się z większą skrupulatnością przyglądać innym dokumentom podejmującym ten sam problem. Mamy ślady działalności fałszerza dokumentów na rzecz biskupstwa w Miśni działającego w czasach cesarza Henryka II. Fałszerz ten sprokurował m.in. kopię naśladowczą dokumentu Ottona III (MGH DD O I, nr 174B), rozszerzoną o interpolację w sprawie granic diecezji. Fałszerstwo to jest tak doskonałe, że gdyby nie zachował się oryginalny dokument (MGH DD O I, nr 174A), ono samo mogłoby uchodzić za oryginał, tym bardziej że dołączono do niego sfałszowaną pieczęć ${ }^{54}$. Na podstawie m.in. tego podfałszowanego dokumentu uzyskano od Henryka III w 1040 r. przywilej (zachowany w oryginale) potwierdzający nadania (MGH DD H III, nr 59).

W czasach biskupa Godebolda (1119/1120-1140) sprokurowano całą serię fałszerstw na rzecz biskupstwa w Miśni, które częściowo zostały spisane tą samą ręką ${ }^{55}$. Mamy więc wspomniany już dokument (MGH DD O I, nr 437) rzekomo wystawiony przez Ottona I w 948 r. w sprawie fundacji biskupstwa i wytyczenia jego granic $^{56}$. W innym, wystawionym rzekomo w 1074 r. przez Henryka IV (MGH DD $\mathrm{H} \mathrm{IV,} \mathrm{nr} \mathrm{275),} \mathrm{fałszerz} \mathrm{sugeruje,} \mathrm{że} \mathrm{donatorem} \mathrm{pewnego} \mathrm{majątku} \mathrm{był} \mathrm{ten} \mathrm{władca,} \mathrm{nie}$

${ }^{52}$ Koronacja cesarska Ottona III odbyła się dopiero $21 \mathrm{~V} 996 \mathrm{r}$.

${ }^{53}$ Taką samą zależność widział, bez podawania szczegółowego uzasadnienia, K. U h 1 i r z, Die ältesten Kaiserurkunden für das Bisthum Meissen, Mittheilungen des Instituts für Österreichische Geschichtsforschung, Ergänzungsband 1, 1885, s. 363-375, tu s. 373, a ostatnio Th. Lu dw i g, Die Urkunden, s. 254.

${ }^{54}$ Por. tamże, s. 248.

55 Tamże, s. $252 \mathrm{n}$.

56 Tamże, s. 260 n.; badacz ten wykazał, że opis granic biskupstwa w MGH DD O I, $\mathrm{nr} 437$, nie jest bezpośrednio zależny od MGH DD O III, nr 186, ale oba sięgają niezależnie do jakiegoś wcześniejszego opisu. 
zaś antykról Rudolf, gdyż obawiano się utraty darowizny uzyskanej od tego ostatniego. Kolejnym fałszerstwem jest rzekomy dokument Henryka IV z 1091 r. (MGH DD H IV, nr 420), który powstał na podstawie oryginalnego dyplomu tego władcy z 1090 r. Ostatnim w tej serii jest rzekomy oryginał (MGH DD H IV 441) datowany na 1097 r., wzorowany na do dziś zachowanym oryginale (MGH DD H IV 410) z 1090 r. Tą samą bądź podobną ręką spisano dyplom wystawiony jakoby w 1071 r. przez biskupa Bennona, który dano do potwierdzenia Innocentemu II w 1140 r. ${ }^{57}$ Fałszerza, którego dzieła tu wymieniliśmy, kilka faktów każe łączyć z naszym DM. Przede wszystkim chodzi o fałszywy dokument Ottona I z 948 r. Opisane w nim granice diecezji zostały częściowo zaczerpnięte z dokumentu Ottona III z 995 r. (MGH DD O III, nr 186) - w DM zaś opis granic jest dalece zbieżny właśnie z tym dyplomem ${ }^{58}$. Fałszerz nasz korzystał zatem z tego samego tekstu, którego ślady odnajdujemy w DM. Trzeba zaznaczyć, że spór terytorialny między biskupami Miśni a arcybiskupami Magdeburga, który zakończony został w 1137 r., toczył się już od lat sześćdziesiątych XI w., a ślady zakusów miśnieńskich biskupów na Dolne Łużyce widać już w 995 r.

VI.

Okoliczności zwołania synodu w Rawennie, odbytego w połowie kwietnia 967 r., są - tak jak je przedstawił W. Jasiński - znacznie udramatyzowane. Autor twierdzi, że Otto I natychmiast po przybyciu do Rzymu w grudniu 966 r. rozpoczął przygotowania do zwołania synodu w Rawennie, wybierając to miejsce ze względu na dogodną komunikacji z ziemiami na północ od Alp (s. 32). Z tego właśnie powodu zwołanie synodu na kwiecień jawi się Autorowi jako przedsięwzięcie niezwykle trudne i pospieszne. Nie można się z tym zgodzić. Przepisy kościelne nakazywały odbyć synod w cztery tygodnie po Wielkanocy i taki właśnie termin został tu zachowany (Wielkanoc 31 marca) ${ }^{59}$. Waga synodu nie była uzależniona od obecności biskupów niemieckich, wystarczyli biskupi środkowo- i północnowłoscy, a dla nich termin był jak najbardziej sprzyjający. Zatem nie musiano przedsiębrać szczególnych kroków ani planować spotkania z dużym wyprzedzeniem, aby ułatwić dotarcie biskupom z Niemiec. Nie było zwyczaju, aby w tym czasie biskupi z północy specjalnie przybywali do Italii, żeby wziąć udział w synodzie, nawet jeśli był na nim cesarz. Pojawiali się natomiast oczywiście biskupi niemieccy znajdujący się w orszaku cesarskim. Nie oczekiwano zatem specjalnej delegacji episkopatu zaalpejskiego, chociaż synod w Rawennie należał do jednego z największych pod względem liczby uczestników w X w. Po drugie, po przybyciu Ottona I do Rzymu odbył się tam w styczniu 967 r. synod, na którym była liczna reprezentacja biskupów, w tym plurimi episcopi ex ultremontano regno (MGH DD O I, nr 336), czyli z Niemiec ${ }^{60}$.

${ }^{57}$ Urkundenbuch des Hochstifts Meissen, t. I, nr 47.

58 Por. szczegółową analizę Th. L u d w i g a, Die Urkunden, s. 254 n.

59 Canones apostolorum, c. 38, oraz sobór z Antiochii z 341 r., c. 20 (Ecclesiae Occidentalis monumenta iuris antiquissima, canonum et conciliorum Graecorum interpretationes Latinae, wyd. C. H. Turner, t. I-II, Oxford 1899-1939, tu t. I, s. 25, t. II, s. 291).

${ }^{60}$ Por. MGH Concilia, t. VI/2, s. 255 n. 
Myli się W. Jasiński, gdy twierdzi, że synod w Rawennie zablokował utworzenie arcybiskupstwa magdeburskiego. W dokumencie Jana XIII wynoszącym Magdeburg do rangi metropolii znajdujemy słowa, że fundacja arcybiskupstwa nastąpiła presente et consentiente sancta sinodo. Podobne stwierdzenie figurują $\mathrm{w}$ dwóch innych dokumentach Jan XIII ${ }^{61}$. Było zatem wręcz przeciwnie, niż dowodzi W. Jasiński - Otto I odniósł sukces, gdyż w porównaniu z próbą erygowania magdeburskiej metropolii z 962 r. moca jedynie autorytetu papieskiego i cesarskiego, wyrażonego dokumentem fundacyjnym (PU nr 154), teraz przedsięwzięcie to wsparto autorytetem synodu. Wystarczyło uzyskać zgodę zainteresowanych biskupów, których prawa mogły zostać przez nową fundację naruszone - arcybiskupa Moguncji i biskupa Halberstadt.

Porzucić należy snutą przez Autora wizję klęski Ottona I, jaką miał ponieść na synodzie w Rawennie. Wprawdzie biskupi jednoznacznie wypowiedzieli się w sprawie prawnych warunków realizacji postanowień (konieczność uzyskania zgody zainteresowanych biskupów), których brak w ówczesnych realiach oznaczał rzeczywistą blokadę projektu. Była to jednak wówczas przeszkoda powszechnie znana i przez wszystkich biskupów (we własnym interesie) zawsze skrupulatnie respektowana. Nie ma powodu sądzić, że Jan XIII i Otto I oczekiwali od synodu rozwiązania siłowego, tj. wymuszenia na zainteresowanych biskupach zgody lub fundacji nowej metropolii bez ich zgody, gdyż było to niemożliwe. Dopuścić chyba można przypuszczenie, że chodziło raczej o wywarcie autorytetem synodu presji na biskupa Halberstadt, żeby taką zgodę wyraził. Kwestia zgody ze strony biskupów w świetle ostatnich badań jawi się zupełnie inaczej. Wszystko wskazuje, że metropolita Moguncji swą zgodę obiecał cesarzowi (lub nawet ją wyraził) już w 966 r. W dokumencie Ottona dla klasztoru Św. Maurycego z 24 VIII 966 r. (oryginał) stwierdzono: qualiter nos interventu dilectę coniugis nostrę Adalheidis et fidelis archiepiscopi nostri Uuillihelmi monasterium - - Deo sanctoque Mauricio Magadaburg perpetualiter serviturum nostra imperiali munificentia liberaliter offerimus et a nostro iure in perpetuum illius aecclessiae ius transfundimus et donamus, ut archiepiscopus ibi a nobis instituendus suique successores omni contradictione remota inoffense teneant et possideant et suis $u$ t res ecclesiasticas iuxta libitum usibus adiungant ${ }^{62}$.

Trudno sobie wyobrazić, aby metropolita moguncki, mając zastrzeżenia co do fundacji Magdeburga, brał udział w darowiźnie, która tak jawnie wskazywała jej przeznaczenie i w której mowa jest o przyszłych metropolitach Magdeburga. Zatem wiosną 967 r. jedyną rzeczywistą przeszkodą był sprzeciw biskupa Halberstadt, w którego diecezji znajdował się Magdeburg. Fundacja biskupstwa w Miśni, którego egzempcja miała w myśl W. Jasińskiego być skierowana przeciw ewentualnym roszczeniom arcybiskupa Moguncji, była w tej sytuacji zupełnie niepotrzebna, natomiast w niczym nie naruszała praw biskupa Halberstadt ${ }^{63}$.

Pozostaje tylko odpowiedź na pytanie, czy brak zgody biskupa Halberstadt na przełomie 967 i 968 r. był wystarczającym powodem do zrekompensowania przez

${ }^{61}$ Zob. MGH Concilia, t. VI/2, s. 261.

${ }^{62}$ MGH DD O I, nr 331. Te same słowa znajdują się w drugim nadaniu dla tej samej instytucji (tamże, $\mathrm{nr} 332$ ).

${ }^{63}$ Szerzej o procesie fundacji arcybiskupstwa w Magdeburgu, por. D. A. S ik or ski, Kościół, s. 375-389. 
cesarza wstrzymania jego planów odnośnie do Magdeburga fragmentaryczną ich realizacją w postaci wcześniejszej fundacji biskupstwa w Miśni. Jeśli tak, to dlaczego tylko tego jednego, skoro w planach Ottona, znanych od wiosny 967 r., były trzy nowe biskupstwa z określonymi już siedzibami, które, podobnie jak Miśnia, nie leżały na terenie innych diecezji. Pod względem formalnym założenie trzech biskupstw nie było trudniejsze niż jednego, tym bardziej że zaplecze organizacyjne w Merseburgu i Żytycach, z utrwaloną władzą ottońską na tych terenach, było znacznie lepiej przygotowane do fundacji biskupstwa niż w Miśni.

Autor podejmuje (s. 9, 30 n.) argumentację Petera Grosfelda, który starał się wykazać, że Burchard został biskupem Miśni jeszcze przed ostatecznym powołaniem metropolii magdeburskiej. Koronnym dowodem ma być wzmianka w liście (oryginał) Ottona I skierowanym jesienią 968 r. do możnych saskich (MGH DD O I, nr 366). Mowa tam o konieczności ordynowania trzech biskupów dla Merseburga, Żytyc i Miśni, z tym że kapłanowi Bosonowi, który miał już duże zasługi dla misji wśród Słowian, pozostawiono wybór między dwiema pierwszymi katedrami, natomiast obsadę drugiej pozostawiono do decyzji metropolity ${ }^{64}$. Ponieważ nie mówi się tam nic o planach wobec Miśni, W. Jasiński sądzi, że biskupstwo to było już obsadzone. Nie zwrócił uwagi na wcześniejsze słowa z tego samego dokumentu: Ne vero hęc eius electio vel inthronizatio futuris quod absit temporibus aliquorum valeat invidia molestari, tres ab illo episcopos: unum Merseburgo, alterum Citice, tertium Misnę, in pręsentia legatorum domni papę et vestra volumus ordinari, ut hęc eadem pressentia vestra ante deum et sanctos eius intentionis nostre sit testis futura [wytłuszczenia - D.S]. Wynika z nich, że żaden z trzech biskupów (ani arcybiskup) nie zostali jeszcze ordynowani. Przypomnijmy, że w DM Burchard jest tytułowany biskupem - nie przyszłym biskupem! Sprzeczności tej nie da się rozwiązać inaczej, jak przyjmując, że informacja z DM jest nieprawdziwa.

Thietmar pisze, że to pierwszy arcybiskup Magdeburga udzielił święceń biskupich Burchardowi. Kronikarz wśród biskupów nowej prowincji rozróżniał tych, którzy byli konsekrowani dopiero teraz, i tych, którzy sakrę otrzymali już wcześniej ${ }^{65}$. W dalszej części wspomnianego listu Otto I (MGH DD O I, nr 366) stwierdza, że dwaj biskupi (Brandenburga i Hawelbergu) mają złożyć nowemu metropolicie wyznanie wiary i posłuszeństwa. Gdyby biskupstwo Miśni funkcjonowało dotąd jako egzymowane, to miejscowy biskup również musiałby złożyć podobne oświadczenie. Zakładając nawet, że biskupstwo zostało formalnie powołane na początku 968 r. w takiej właśnie formie prawnej, jaką postuluje W. Jasiński, a Burchard zdążył otrzymać jedynie inwestyturę, ale nie zdążył do jesieni tego roku uzyskać święceń biskupich, to jak wytłumaczyć brak w piśmie Ottona I bardziej szczegółowej wzmianki o istniejącym

${ }^{64}$ MGH DD O I, nr 366: Et quia vir venerabilis Bǒso multum iam in eadem Sclavorum gente ad Deum convertenda sudavit, inter Merseburgensem et Citicensem aecclesiam quam velit electionem habeat, altera vero secundum convenientiam nostram in dispositionem archiepiscopi nostri cedat.

${ }^{65}$ Die Chronik des Bischofs Thietmar von Merseburg, lib. II, c. 22, wyd. R. Holtzmann, MGH, Scriptores rerum Germanicarum, nova series, t. IX, Berlin 1935, s. 64: Super hęc domni episcopi Dudo et Dodelinus in archiepiscopi nostri electione volumus ut subscribant et fidem subiectionemque illi promittant. 
biskupie elekcie miśnieńskim, skoro w tym samym tekście pada imię jednego kandydata, który ma dopiero dokonać wyboru, oraz imiona pozostałych dwóch biskupów (Brandenburga i Hawelbergu). Jak wytłumaczyć tak długą zwłokę (przynajmniej 10 miesięcy) w uzyskaniu święceń przez Burcharda, skoro nie było - o ile nam wiadomo - jakichkolwiek kontrowersji w związku z jego kandydaturą. Prawdopodobnie kwestia obsady biskupstwa w Miśni w momencie sporządzania pisma (późna jesień 968 r.) nie była rozstrzygnięta, podobnie jak dwóch pozostałych. Wszystkie trzy biskupstwa ze względu na relatywną słabość majątkową nie miały większego znaczenia, zatem ich obsada nie musiała być efektem politycznych pertraktacji. Warto przypomnieć, że także kandydatura Adalberta jako przyszłego arcybiskupa Magdeburga padła w ostatniej chwili. Sądzę zatem, że list Ottona I z jesieni 968 r. nie dowodzi bynajmniej wcześniejszego erygowania biskupstwa w Miśni, daje natomiast przesłanki osłabiające tezę o autentyczności DM.

VII.

Tekst DM budzi kilka wątpliwości o charakterze prawno-kanonicznym. Przede wszystkim dokument ma dwóch odbiorców: klasztor Św. Jana Ewangelisty oraz biskupstwo w Miśni, co jest faktem niezwykłym, pomimo tego, że na czele obu instytucji miała stać ta sama osoba. O ile dyspozycje dotyczące klasztoru są powtórzeniem (nie w całości) tych znanych nam z dokumentu hersfeldzkiego, o tyle te dotyczące biskupstwa - najczęściej interpretowane jako udzielenie egzempcji biskupstwu w Miśni - są w rzeczywistości niezrozumiałe. Najważniejsza część zawarta została w następującym fragmencie (fragmenty najważniejsze wyróżniam wytłuszczeniem, a zapożyczenia Pseudo-Izydora zostały dodatkowo podkreślone): Et ideo in Christo sanccimus firmiterque concessimus, ut nullus metropolitanus, nullus episcopus, nulla etiam magna vel parva alterius ordinis et gradus persona preter sedis apostolice antistitem infra terminos Misnensis ecclesie, cui venerabilis episcopus Burcardus preesse dinoscitur, quemquam ordinare, diiudicare, excommunicare vel aliquid temere exercere ullo modo presumat.

W. Jasiński znajduje tu ślady znajomości Pseuso-Izydora i przypisuje w związku $\mathrm{z}$ tym autorstwo notariuszowi Stefanowi, a nie domniemanemu trzynastowiecznemu fałszerzowi. Jak już wyżej wspomniałem, wniosek taki jest zbyt pochopny, gdyż zakłada, że tylko w tym czasie możliwe było odwołanie się do Pseudo-Izydora. Kontrprzykładem może być sfałszowany dokument Marinusa II dla klasztoru Volturno datowany na 944 r. (PU nr 104). Znajdujemy tam również słowa: ut nullus episcopus debeat - - quoquo modo iudicare vel excommunicare. Fałszerstwo powstało w bliżej nieokreślonym czasie, ale przed połową XII w., gdyż wykorzystane zostało przez Piotra Diakona $^{66}$. Podobne zapożyczenie znajdziemy nawet w dwunastowiecznych autentykach, jak np. bulla Lucjusza z 1144 r.: nec alterius parochianos iudicare aut excommunicare praesumat $^{67}$. W żadnym $\mathrm{z}$ tych dokumentów nie chodziło o egzempcję biskupstwa.

${ }^{66}$ H.-H. K o r t ü m, Zur päpstlichen Urkundensprache im frühen Mittelalter. Die päpstlichen Privilegien 986-1046, Sigmaringen 1995, s. 242-250, zwł. s. 249.

67 Bullarum, diplomatum et privilegiorum sanctorum Romanorum pontificum Taurinensis editio, wyd. F. Gaude, 1859, s. 488. 
Istotą egzempcji biskupstwa było wyłączenie go spod więzi metropolitalnych wyrażających się w X w. głównie prawem metropolity do udzielania konsekracji. W dokumencie nie ma o tym najmniejszej wzmianki czy nawet sugestii, kto ma mieć prawo konsekracji biskupów Miśni. Już w pierwszych przywilejach egzempcyjnych dla biskupstw kwestia konsekracji jest jasno formułowana ${ }^{68}$. Z założenia metropolita - podobnie jak każdy inny biskup - nie miał prawa do żadnych czynności kościelnych w innej diecezji, nawet jeśli było to biskupstwo-sufragania. W tych okolicznościach nie ma sensu wyrażone w DM zastrzeżenie: ut nullus metropolitanus, nullus episcopus, nie mówiąc już o włączeniu kolejnych osób: nulla etiam magna vel parva alterius ordinis et gradus persona. Podobnie absurdalnie odnośnie do egzempcji biskupstwa brzmi ciąg dalszy, określający, czego zabrania się wyżej wymienionym, mianowicie: quemquam ordinare, diudicare, excommunicare vel aliquid temere exercere ullo modo presumat. Zwroty te brzmią również nieadekwatnie do przypisywanej im roli postanowień egzempcyjnych, gdy przyjmiemy, że mają odzwierciedlać idee pseudoizydoriańskie, gdyż u Pseudo-Izydora nie znajdziemy idei egzempcji biskupstw; zajmował się on jedynie regulacją stosunków metropolitów z sufraganami, a biskupstwo egzymowane nie należało do żadnej metropolii. Należy podkreślić, że papiestwo nie przejmowało roli metropolity wobec biskupów egzymowanych. W przypadku Miśni położenie nacisku na ochronę przed roszczeniami metropolity wydaje się tym bardziej nieuzasadnione, że biskupstwo to nie miało być wyłączone $\mathrm{z}$ dotychczasowego związku metropolitalnego, gdyż w żadnym dotąd nie było, ale od początku miało być egzymowane. Nie było więc metropolity, który mógłby postanowienia papieża kontestować i uważać, że naruszone zostały jego prawa, przeciwko któremu skierowane byłoby zastrzeżenia nullus metropolitanus.

Zastanawiać musi w DM - jeśli miał by to być autentyk - brak postanowienia, które sankcjonowałoby ustalenie katedry w kościele klasztoru Św. Jana Ewangelisty, jak ma to miejsce np. w dokumencie powołującym arcybiskupstwo w Magdeburgu $^{69}$. Trudno widzieć w DM akt erekcji biskupstwa, gdyż treść odnosi się jedynie do granic, ale wymowa jest taka, jakby biskupstwo już istniało. Przypomnijmy, że biskupstwo w Miśni miało swój „dokument fundacyjny” - był to sprokurowany w środowisku miśnieńskim w XII w. fałszywy dokument rzekomo z 948 r., w którym Otto I miał już wówczas ufundować biskupstwo ${ }^{70}$. Jeżeli uznamy DM za falsyfikat,

${ }^{68}$ Por. D. A. S i k or s k i, O rzekomej instytucji biskupstwa bezpośrednio zależnego od Stolicy Apostolskiej. Przyczynek do problemu statusu prawnego biskupów polskich przed rokiem 1000, Czasopismo Prawno-Historyczne 52, 2003, z. 2, s. 157-185; powoływanie się W. Jasińskiego na pracę A. W e i s s a, Biskupstwa bezpośrednio zależne od Stolicy Apostolskiej w średniowiecznej Europie, Lublin 1992, jest, ze względu na jej ogromne braki warsztatowe, po prostu nieporozumieniem.

${ }_{69} \mathrm{PU} \mathrm{nr}$ 154: hanc privilegii paginam iubemus, ut Magdaburgense monasterium in regno Saxonum iuxta Albia (m) constructum - - in archiepiscopalem transferatur sedem; i nieco dalej o powołaniu biskupstwa w Merseburgu: ut Merseburgense monasterium - - in episcopalem delegetur sedem; PU nr 177 (kwiecień 967 r.): statuentes presente et consentiente sancta sinodo et ipso inperatore, ut Magdaburche sita iuxta Albiam fluvium - - deinceps metropolis sit.

${ }^{70}$ MGH DD O I, $\mathrm{nr} \uparrow 437$ : aecclesiam quandam in Misina civitate collocari et construi praecepimus, ubi etiam rogatu et consilio universorum principum nostrorum in honore sancti Johannis ęvangelistę sedem episcopalem fieri decrevimus; opis granic na podstawie MGH O III, nr 186 z 995 r. 
to wpasowuje się on w wizję historii lokalnego Kościoła, wedle której biskupstwo powstało w 948, a w 968 r. papieski przywilej potwierdził granice i nadał pewne przywileje klasztorowi.

VIII.

Próba wykazania przez W. Jasińskiego, że dokument Jana XIII z 968 r. dla Miśni jest autentykiem, nie wytrzymuje krytyki. Wszystkie przytoczone przez Autora argumenty, mające świadczyć za autentycznością, okazały się niewystarczające lub chybione. Sądzę, że rzekomy dokument Jana XIII dla Miśni powstał jako fałszerstwo w pierwszej połowie XII w. (przed $1131 \mathrm{r}$.) w związku z większością tzw. fałszerstw miśnieńskich. Ponieważ w połowie XIII w. na nowo wybuchł spór o dziesięciny, starano się wzmocnić wymowę tego fałszerstwa przez uwierzytelnienie go w postaci widymusu.

Jeżeli dokument ten okazuje się nieautentyczny, nie ma zatem znaczenia dla dziejów polskiego Kościoła.

\section{ANEKS}

Tekst rzekomego dokumentu Jana XIII dla klasztoru i biskupstwa w Miśni z 2 I 968 r. (za PU nr †187)

W tekście zaznaczono czcionką prostą tekst znany wyłącznie z DM, kursywą - tekst zgodny z DH, a wytłuszczoną - tekst wspólny z MGH DD O III, nr 186; tekst zapożyczony z MGH DD D I, nr 406, lub z DD O III, nr 186 został podkreślony, natomiast tekst wspólny dla MGH DD O II, nr 184, oraz DD O III. nr 186 ujęto w nawiasy kwadratowe [ ].

Johannes episcopus, servus servorum Dei.

Si semper sunt concedenda, que piis desideriis congruunt, quanto potissimum ea, que divini cultus prerogativa noscuntur, non sunt omnino abneganda, que sunt a largitoribus non solum poscenda, sed vi caritatis procul dubio exigenda. Habita igitur sinodo et multorum venerabilium patrum coepiscoporumque nostrorum conventu Romę in ęcclesia beati Petri principis apostolorum, assidentibus augustissimis imperatoribus Ottonum utrisque, anno scilicet imperii maioris sexto, minoris primo, idem gloriosissimi imperatores postulant a nobis, quatenus monasterium, quod pro remedio animarum suarum primitus construi et in honore beati Johannis Ewangeliste consecrari fecerunt super ripam fluminis, cui nomen est Albia, in civitate Misnae sita, videlicet in provincia que dicitur Talemence, cui etiam monastorio virum venerabilem nomine Burcardum honorifice prefecerunt, privilegiis apostolice sedis decoraretur, ut sub iurisdicione sancte ecclesie nostre, cui Deo auctore presidemus, constitutum nullius alterius ecclesie dicionibus submittatur. Pro qua re piis desideriis faventes hac nostra auctoritate id, quod exposcitur, effectui mancipamus, interponentes tamen ea, que et ipsi principes nostri in nostris privilegiis cupiunt exponi et cunctis in Christo fidelibus manifesta fieri. More antiquorum imperatorum hii duo imperatores, pater et filius, nobis assidentes Misnensi episcopatui terminum inposuerunt nominando fines et determinationes locorum, sicut infra tenetur: Ubi caput et 
fons et aque que dicitur Odera inde quasi recta via usque ad caput Albie, inde deorsum in occidentalem partem, ubi divisio duarum regionum est Behem et Nisen, ibidem ultra Albiam et per silvam in occidentalem partem usque ad caput Milde et sic deorsum [per ambas plagas] eiusdem fluminis usque dum Milta intrat in Albiam $<{ }^{71}>$ et sic sursum et ultra provinciam Nizizi ad ipsum terminum sine dubio necnon in altera parte Luzice et Selpoli et sic usque ad civitatem Sulpize, illam videlicet infra eundem terminum et inde in aquam que dicitur Odera et sic Odera sursum usque ad caput eius. Omnes vero, quemadmodum hii presentes imperatores statuisse fatentur, qui infra terminurn istum habitant, in omni fertilitate terre, [frugum et pecudum], in argento, vestimento [necnon quod Teutonici dicunt oborcoufunga et talunga familiarum], insuper tota utilitate et in omnibus rebus, [quibus mortales utuntur] in diversis modis, decimationes, quas Deo cuncta gubernanti debent ad Misnensem ecclesiam, primo Deo, deinde sancto Johanni Ewangeliste universa dubietate [procul remota persolvant, more antiquorum imperatorum reforant et reddant]. $\left\langle{ }^{72}\right\rangle$ Et ideo in Christo sanccimus firmiterque concessimus, ut nullus metropolitanus, nullus episcopus, nulla etiam magna vel parva alterius ordinis et gradus persona preter sedis apostolice antistitem infra terminos Misnensis ecclesie, cui venerabilis episcopus Burcardus preesse dinoscitur, quemquam ordinare, diiudicare, excommunicare vel aliquid temere exercere ullo modo presumat. Statuentes etiam apostolica censura sub divini iudicii obtestatione et validis atque atrocibus anathematis interdictionibus, ut nullus imperator posthac aut rex ullus sive quispiam alius, cuiuscumque dignitatis sit potestate preditus, eiusdem ecclesie causis presumat incumbere vel minimum quiddam ex hiis, que ad illud monasterium sancti Johannis pertinere videntur, cui episcopus Burcardus presidet, aut sibi temere vindicare aut alicui magne parveque persone pro beneficio dare aut quolibet modo inde auferre vel alienare audeat. Promulgamus etiam et hoc auctoritate beati Petri apostolorum principis coram Deo et terribili eius futuro examine per huius nostri privilegii atque constituti vim interminamus, ne quis mortalium sibi licere existimet aliquid ex possessionibus Misnensis ecclesie,

${ }^{71} \mathrm{~W}$ tym miejscu znajduje się interpolacja niemal w całości zgodna z MGH DD O III, $\mathrm{nr}$ 186: necnon ob hoc diximus in occidentali plaga, quia multe ville pertinent ad orientales urbes infra eundem terminum.

${ }^{72} \mathrm{~W}$ tym miejscu znajduje się interpolacja (kursywą zaznaczono tekst zapożyczony z MGH DD O I, nr 406, z 971 r., a podkreśleniem z MGH DD DO II, nr 184 z 983 r.): Testantur etiam iidem presentes nobilissimi imperatores quasdam res sui iuris ac proprietatis eidem sancte Misnensi ecclesie, cui venerabilis episcopus Borchardus preesse dinoscitur, pro remedio animarum suarum in proprium dedisse, hoc est tributorum suorum in quinque regionibus partes decimas in Talemence, in Nisanen, in Luzice, in Milczsane, in Diedesa, ut antea quam comes earundem regionum partem sibi ab ipsis concessam auferat atque distribuat, decimas per totum et per integrum iam dicte sancte Dei ecclesie persolvat, id es in melle, crusina, solutione argenti, mancipiis, vestimentis, porcis, frumento et in omnibus rebus, que ad fiscum predictorum imperatorum pertinere videntur. Asserunt etiam hii presentes gloriosissimi imperatores sancte Misnensi ecclesie necnon sancto Johanni Ewangeliste sui iuris theoloneum a civitate quo dicitur Belegora usque ad eiusdem Misnensis ecclesie portum sursum indeque denuo per ambas plagas prefati fluminis Albie deorsum sicque infra prefinitum terminum, ubicumque manus negotiatorum ultra Albiam huc illucque sese diverterit, ex integro et absque ulla contradictione eidem prenominatae sedi Misnensi persolvi et tradi et perenniter constituisse. 
tam ex hiis, que antehac a gloriosissimis imperatoribus Ottone et eius equivoco filio vel a ceteris Christianis eidem sancto loco oblata atque collata sunt, quam que postmodum sunt conferenda, ut profecto iuxta id, quod subiectum est, idem venerabilis locus hoc apostolico privilegio inconcusse donatus permaneat. Si quis autem, quod minime optamus, nefaria auctoritate hec, que a nobis ad laudem Dei pro stabilitate sepe dicti monasterii statuta sunt, refragare presumpserit nostrique precepti transgressor exstiterit, sciat se anathematis vinculo innodatum et cum dyabolo atque Juda, traditore domini nostri Jesu Christi, eterni incendii supplicio deputatum. At vero qui pio intuitu huius apostolici instituti observator exstiterit, benedictionis gratiam a misericordissimo Domino Deo multipliciter consequatur et vite eterne particeps effici mereatur.

Scriptum per manus Stephani scriniarii sancte Romane ecclesie in mense Decembri, indictione undecima.

\section{Über die angebliche Stiftung des Bistums Meißen am 2. Januar 968}

\section{Zusammenfassung}

Der Verfasser des vorliegenden Aufsatzes polemisiert gegen den Versuch von Wojciech Jasiński, die Echtheit des von Johannes XIII. am 2. Januar 968 zugunsten des Abtes und Bischofs von Meißen Burkhard ausgestellten Privilegs zu erweisen. Detailliert wurden sowohl die älteren, aus der Literatur bekannten als auch die neuen, von W. Jasiński vorgestellten Argumente, die angeblich für die Echtheit der Urkunde sprechen, diskutiert. Denn alle Beweisführungen erweisen sich als nicht überzeugend oder gar falsch. Weder die diplomatische Analyse noch die von W. Jasiński vermuteten historischen Umstände oder die Hinzuziehung des kanonisches Rechts halten der Kritik stand. W. Jasiński konnte vor allem nicht überzeugend darlegen, warum das Privileg Johannes' XIII. teilweise Textpassagen beinhaltet, die in späteren ottonischen Urkunden wiederkehren, ohne auf die vermeintliche Vorlage zu verweisen. In diesem Aufsatz wird daher aufgezeigt, daß die Meißner Urkunde - die vom Verfasser gänzlich für eine Fälschung gehalten wird - in einen breiteren historischen Kontext gestellt werden kann, vor allem in den Zusammenhang mit den in der ersten Hälfte des 12. Jahrhunderts zugunsten des Bistums Meißen ausgefertigten Fälschungen. Die Meißner Urkunde ist daher für die Kirchengeschichte Polens von keinerlei Bedeutung.

Übersetzt von Waldemar Könighaus

\section{On the supposed foundation of a bishopric in Meissen on 2 January 968}

\section{Abstract}

The paper is a polemic with Wojciech Jasiński's attempt to prove the authenticity of the document issued by John XIII on 2 January 968 for Burkhard, abbot of the monastery and bishop of Meissen. Both old arguments known from the literature and the new ones put forward by Wojciech Jasiński, which are supposed to speak for the authenticity of the document, are discussed in great detail. All of them turn out to be either unconvincing or wrong. Neither diplomatic analysis, nor the historical and legal circumstances assumed by Jasiński stand up to scrutiny. First of all, Jasiński does not explain why the document of John XIII contains in part a text which later appears in Ottonian documents without references to it. The article shows 
that the Meissen document - which the author considers to be a forgery in it entirety - may be placed within a wider historical context, especially that of other forgeries for the benefit of the bishopric of Meissen, produced in the first half of the $12^{\text {th }}$ century. Thus the Meissen document is of no value for Church history in Poland. 